\title{
Flood risk analysis: causes and landscape based mitigation strategies in Dire Dawa city, Ethiopia
}

\author{
Sitotaw Haile Erena ${ }^{1 *}$ and Hailu Worku ${ }^{2}$
}

\begin{abstract}
Background: In flood prone areas, understanding flood causing factors, assessing the flood induced risks and adopting landscape based mitigation strategies can increase the knowledge, awareness and individual initiatives to protect themselves and their properties using appropriate flood management measures before and during flood events. Dire Dawa city is located in the foothill of southern mountains from where rivers crossing the city are originated. The multidimensional causes of flood hazard and limited landscape based mitigation strategies in the study area have worsen the impacts of flooding. This study was conducted in the Dire Dawa city watershed with the aims of assessing flood causing factors and to propose landscape based flood mitigation strategies.

Results: To meet the intended objectives, the study employed the collection of both primary and secondary data. The primary data were collected from 110 households located in flood vulnerable villages. Moreover, the secondary data were collected from the Ethiopian Meteorology Agency, land use map of Dire Dawa city administration and government reports. Rainfall index method and descriptive statistics were used for analysis of primary data. The former was used to check the effect of intense rainfall and flood risk in terms of different duration yearly, monthly, daily and hourly basis, while the latter was used for identification of various factors precipitating flood risks of the study area. The analysis of secondary data employed morphometric analysis so as to identify flood susceptible subwatersheds. Findings of the study indicated that flood risk in the study area has resulted from multiple factors such as intense rainfall, topography, encroachment to the river banks, institutional problems and aggravating factors resulted from power interruption during heavy rain and regime changes. More importantly, flood risk of the study area was found to be sensitive to hourly variation of rainfall distributions and varies on the location of the sub-watersheds. Following that, flood susceptibility of sub-watershed was ranked based on linear and shape morphometric parameters where higher values of linear and lower values of shape parameters were attributed to high flooding risk. Based on the prioritization of sub-watersheds' susceptibility to flood risk through morphometric analysis, sub-watershed 5 and 18 were identified as the most flood risk susceptible watersheds demanding urgent landscape-based conservation measures. To this end suitable sites and sustainable water conservation structures are identified across the watersheds.

Conclusion: Check dams, terracing, nala bunds, percolation tanks and storage tanks were proposed for different locations across the watershed as effective landscape-based flood risk mitigation strategies. The overall results of the study shows that managing the root causes of flooding at the upper catchments and adopting recommended proposed water conservation structures at proposed site helps to sustainably curb flood induced risks of Dire Dawa city.
\end{abstract}

Keywords: Flood causes, Landscape, Morphometry, Mitigation strategies

\footnotetext{
* Correspondence: sitotahaile@yahoo.com

${ }^{1}$ School of Geography and Environmental Studies, Haramaya University, Dire

Dawa, Ethiopia

Full list of author information is available at the end of the article
} 


\section{Background}

Flood is one of the leading natural hazards worldwide both in terms of the frequency of occurrence and the resulting damages to human lives, the environment, and economic assets (Jonkman 2005; Doocy et al. 2013). The occurrence of flood depends on meteorology, topography, land use, soil type, and antecedent moisture conditions (Funk 2006; Youssef et al. 2016; Agbola et al. 2012). The multi-dimensional causes of flood made it less predictable and aggravated its impacts worldwide. In the coming decades, the effect of climate change and urbanization is expected to exacerbate flood induced risks (Nijland 2005; International Strategy for Disaster Reduction (ISDR) 2008). Compared to rural areas that yield $25 \%$ of surface runoff, urban watersheds lose about $90 \%$ of the storm rainfall to runoff (Shang and Wilson 2009). This shows that urban flood incidents are expected to increase as a result of high rate of urban growth (Lenderink and van Meijgaard 2008; Miller and Hutchins 2017).

As flood risk and its impacts are increasing from time to time, emphasis was given by flood research scholars to understand the root causes of flood risk and its mitigation strategies. To this end, different researchers identified various factors triggering urban flooding. For example, Youssef et al. (2016) and Dawod et al. (2012) carried out a detailed analysis on causes of flash flood in Jeddah city and identified various factors such as heavy rainfall, topography, effect of climate change and characteristics of the drainage networks of the city. Similar study conducted in Nigeria (Ologunorisa and Adejumo 2005; Agbola et al. 2012) revealed that flood was caused by encroaching to riverbanks, poor housing, lack of early warning information, dam breaking, heavy rainfall, dumping solid waste in drainage channels and land use changes. Many of the previous studies conducted on causes of flood risk and mitigation strategies confirmed that flood triggering factors are mainly derived from meteorological, hydrological and anthropogenic effects (Funk 2006; Agbola et al. 2012; Youssef et al. 2011).

Dire Dawa city is located at foothills of the mountains located in the southern part (Fig. 1). The flooding in Dire Dawa occurs as a result of its geographical location, topography, and rainfall pattern of the city watershed. This shows that the flood risk studies of Dire Dawa city

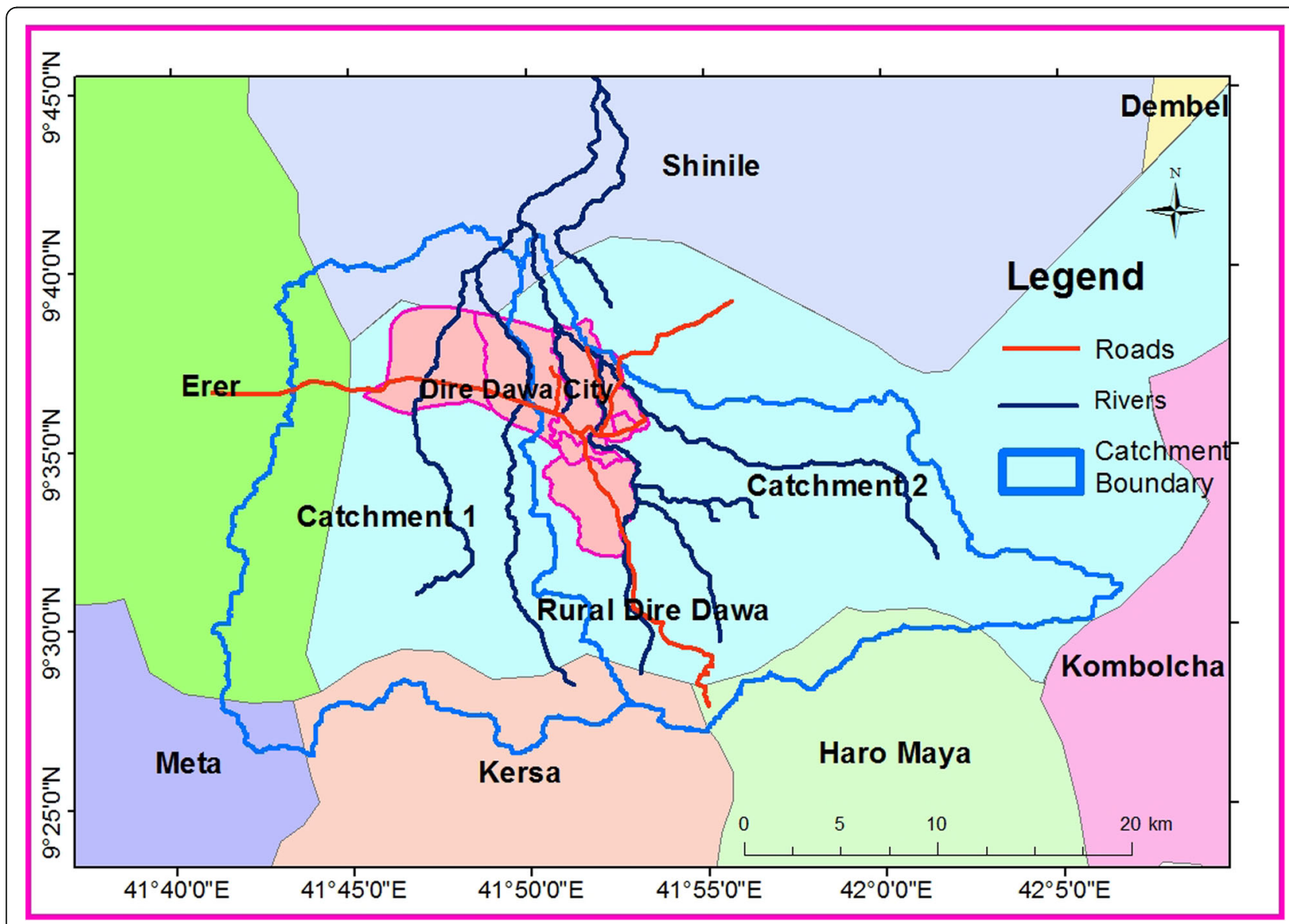

Fig. 1 Map of Dire Dawa city watershed 
demands watershed level analysis and planning strategies that can be done across the political boundaries.

Flood risk has been historically affecting Dire Dawa city since the establishment of the city. Even though, adequate records on urban floods of Dire Dawa city were patchy and incomplete, historical information revealed that the first damaging flood risk was recorded in 1945. Since then flood has been affecting the city at different times. Different authors have investigated the causes of flood in Dire Dawa city with respect to geomorphology, hydrology and land use changes within the city boundary (Yonas 2015; Girma and Bhole 2015; Alemayehu 2007). The municipality has also been constructing flood protection walls around the banks of Dechatu and Goro Rivers to protect the city from flood induced damages. Despite all these efforts, flooding has continued to cause damage to human lives and properties of the city each year. This demands a detailed analysis of flood causing factors of the study area and proposing appropriate landscape-based mitigation strategies in and outside of the city boundaries.

The study of flood and flood management strategies require the estimation of flow of water in river channels (Chandniha and Kansal 2017; Bouwer 2013). However, runoff estimation in ungauged stations is very challenging (Nyamathi and Kavitha 2013). The study of physical behavior of the catchment helps to understand the hydrologic and geomorphic conditions that causes flooding and soil erosion (Eze and Efiong 2010). In this case morphometric analysis helps to better understand the hydrologic characteristics and watershed information of the basins (Horton 1945; Strahler 1964a, b; Krishnamurthy et al. 1996). Many of the earlier studies on morphometric analysis focused on drainage basins and their geometric characteristics such as topology, texture pattern, shape, and relief characteristics used to predict flood peaks, sediment yields, and estimation of erosion rates (Abrahams 1984; Gardiner 1990). However, this study aims at combining morphometric analysis with watershed geomorphologic characteristics to estimate and rank levels of flood risk at different sub-watersheds (Kumar et al. 2000; Youssef et al. 2011; Singh et al. 2014).

Flood is mainly the result of increase in surface runoff. Reduction of surface runoff can be achieved by constructing suitable structures such as ponds, percolation tanks, storage tanks, and check dams (Kumar et al. 2016; Youssef et al. 2016; Agarwal et al. 2013; Chowdary et al. 2013; Jung et al. 2013) used to collect excess waters. Effective way of water harvesting system heavily depends on identification of suitable sites (Ammar et al. 2016, Al-Adamat et al. 2012; Panhalkar and Gowtham 2011). The identification of suitable water harvesting sites are made using the combined criterion of FAO and Integrated Mission for Sustainable Development (IMSD) guidelines that employ slope, soil, permeability, land use land cover and stream orders of the watershed (Prinz and Singh 2000; FAO 2003; Panhalkar and Gowtham 2011). The objectives of this study are (i) to explore the causes of flood risk in Dawa city; (ii) to identify flood susceptible sub-watersheds in the study area; and (iii) to propose landscape based suitable and sustainable water detention and retention structures.

\section{Methods \\ Study area}

The study area, Dire Dawa City, is located in the great East African rift valley between $9^{0} 25^{\prime} \mathrm{N}$ and $9^{\circ} 45^{\prime} \mathrm{N}$ latitude and $41^{\circ} 40^{\prime} \mathrm{E}$ and $42^{\circ} 10^{\prime} \mathrm{E}$ longitude. It is bordered in the North, East, and West by Somali Regional State and in the South and South west by Oromia Regional State. The city is located along the foothills of surrounding mountains drained by tributaries of five major rivers, Dechatu, Goro, Laga Hare, Butuji and Melka Jabdu. Dechatu, the largest river, runs through the heart of the city. All these rivers are coming from the southern mountains originating from the districts of Oromia Regional States (Kombolcha, Haramaya, Kersa and Meta) Fig. 1.

Dire Dawa Administration Council is composed of urban and rural areas. The combined area of urban and rural Dire Dawa covers an area of $1288 \mathrm{~km}^{2}$. Dire Dawa city watershed comprises the surrounding districts of Oromia and Somali Regional States. The watershed covers an area of $698.5 \mathrm{~km}^{2}$. The elevation of Dire Dawa ranges from 1000 to $1600 \mathrm{~m}$ above sea level. The elevation of mountains in the watershed reaches up to $2400 \mathrm{~m}$ above sea level. Dangago is the highest mountain located at the upper part of the watershed. Based on 2013 projected statistical report of Ethiopia, Dire Dawa city population is estimated at about 466,000 with annual growth rate of $2.7 \%$ (CSA 2013). By the virtue of being surrounded by various mountains and drained by the tributaries of several major rivers, the city has always been subjected to periodic flooding. The recall of elders and flood related reports of the city indicate that major floods have occurred in 1945, 1968, 1977, 1983, $1985,1995,2003,2005,2006,2010$, and 2016 due to flash flood coming from surrounding mountains (Table 1). Among these, the 2006 flood that caused a death of 339 human deaths and 9027 displacements was the most catastrophic.

\section{Methods}

This study considered both primary and secondary data to achieve the intended objectives of the study. To collect the primary data, a structured questionnaire were designed and administered in the selected villages using purposive and systematic random sampling method. The selection of villages was determined purposely to address 
Table 1 Summary of flood induced risks in Dire Dawa city watershed since 2006

\begin{tabular}{lllll}
\hline Village /city & Human loss & Livestock loss & Property loss & Remarks \\
\hline Metokomia & 2 & Not stated & Not stated & 9027 People were displaced \\
Biftu Geda & 5 & 11 & Not stated & 200 houses, roads and bridges \\
Dire Dawa city & 339 & 21 & 178 ha crops \\
lja Anani & 2 & 27 & 80 ha crops and 40 Houses \\
Harala Balina & 4 & 900 & Not stated \\
Lazaret & 22 & 200 & 3 houses \\
Shinile & Not stated & 1100 & 268 ha crops, 243 houses \\
Total & 374 &
\end{tabular}

Source: Compiled from Dire Dawa city flood assessment unpublished report (2006-2016)

villages vulnerable to flood hazards. Accordingly, based on Dire Dawa city flood prone village reports, 4 villages (05, 06, 07 and 09) were purposely identified as flood vulnerable areas. Sample households from each village were then selected using systematic random sampling. Accordingly, from 1163 households that fall in flood vulnerable villages, $10 \%$ (110) households were picked for household survey sampling. The final selection of sample households of each of the four villages was done using random sampling method.

Apart from primary data sources, flood causative analysis employed the analysis of land use land cover changes using different decade satellite imagery analysis. Considering the relationship between regime change and land use policy of the country, four land use maps from satellite remote sensing at about 10 years interval (1985, 1995, 2006 and 2016) were selected for land use land cover change analysis. This helped to know the decadal urban growth change and direction of urban expansion. In addition to this, the precipitation based cause of flood hazard analysis employed time series analysis of rainfall data obtained from Dire Dawa (1953-2014), Dangago (1986-2014) and Haramaya (1960-2013) meteorological stations to detect climate variability. The frequency distribution of hourly rainfall was assessed by identifying the number of days having maximum hourly rainfall exceeding $30 \mathrm{~mm}$. The daily rainfall distribution of each years and standardized hourly rainfall index was computed and examined for Dire Dawa, Haramaya and Dangago stations based on FAO (1998) using Eqs. 1, 2 and 3.

$$
\mathrm{Z}=\left(x_{i}-\bar{x}\right) / \sum d
$$

If $Z<-1$, it would be below normal

If $-1 \leq Z \leq 1$, it would be normal

$\mathrm{Z}>1$, it would be above normal

Where, $\mathrm{Z}=$ Standardized minimum rainfall anomaly

$\sum$ d Standard deviation

$\bar{x}$ Mean hourly rainfall records

$x_{i}$ Observed hourly rainfall
When dealing with extremes, it is important to employ the probability of return period (eq. 2). If ' $\mathrm{P}$ ' is the probability that the event will be equaled or exceeded in particular year then the return period ' $\mathrm{T}$ ' may be expressed.

$$
\mathrm{T}=\mathrm{N}+1 / \mathrm{m}
$$

Where, $\mathrm{m}$ is order or rank of the event

$\mathrm{N}$ is total number of event in the data

$\mathrm{T}$ is return period

In different methods, the probability of occurrence of a particular extreme rainfall is important and such information is obtained by the frequency analysis of rainfall data (eq. 3).

$$
P=1 / \mathrm{T}
$$

Where $\mathrm{T}$ is return period

$\mathrm{P}$ is probability

To meet the objective of landscape based flood mitigation strategy, the analysis of morphometric parameters was employed. Morphometric parameters were used to identify highly erosion sensitive sub-watersheds that may require highest priority of intervention for conservation activities. The watershed prioritization has been done based on the linear and shape aspects of morphometric analysis. The linear parameters such as drainage density, stream frequency, bifurcation ratio, texture ratio have a direct relationship with flooding. Higher value of linear parameters means high flood. Hence for the prioritization of the sub-watershed the values with highest linear parameter are ranked as 1 . The next highest are ranked as 2 and the rank continues for all sub-watersheds. On the contrary, shape parameters such as elongation ratio, compactness constant, circulatory ratio and form factor have an inverse relationship with flooding. The lower values means the more the flooding is. Hence for the prioritization of the watershed the values with lowest shape value are ranked as 1 . The next lower value is ranked as 2 and the same procedure was applied for all the sub- watersheds. Prioritization rating of all the subwatersheds was carried out by calculating the compound 
Table 2 Formula for computation of morphometric parameters

\begin{tabular}{|c|c|c|c|}
\hline No & Morphometric Parameters & Formula/ definitions/methods & References \\
\hline \multicolumn{4}{|c|}{ Linear aspect } \\
\hline 1 & Stream order & Hierarchical order & Strahler 1964a, b \\
\hline 2 & Stream Length (Lu) & Length of the Stream (km) & Horton 1945 \\
\hline 3 & Mean Stream Length (Lsm) & $\begin{array}{l}\mathrm{Lsm}=\mathrm{Lu} / \mathrm{Nu} \text {, Where, } \mathrm{Lu}=\text { Total Stream length of order ' } U \text { ', } \\
\mathrm{Nu}=\text { Stream length of next higher stream order. }\end{array}$ & Horton 1945 \\
\hline 4 & Stream length Ratio(RI) & $\begin{array}{l}\mathrm{RI}=\mathrm{Lu} / \mathrm{Lu}-1 \text {; where, } \mathrm{Lu}=\text { Total number of stream segment } \\
\text { of order ' } \mathrm{U} \text { ', } \mathrm{Lu}-1=\text { Stream length of next lower order }\end{array}$ & Horton 1945 \\
\hline 5 & Bifurcation Ratio (Rb) & $\begin{array}{l}\mathrm{Rb}=\mathrm{Nu} / \mathrm{Nu}+1 \\
\text { Where, Nu = Total Number of stream segments of order ' } \mathrm{U} \text { ' } \\
\mathrm{Nu}+1=\text { Number of segments of the next higher order. }\end{array}$ & Schumm 1956 \\
\hline \multicolumn{4}{|c|}{ Areal aspect } \\
\hline 6 & Drainage Density (Dd) & $\mathrm{Dd}=\mathrm{L} / \mathrm{A}$ Where, $\mathrm{L}=$ Total length of Stream, $\mathrm{A}=$ Area of the Watershed & Horton 1945 \\
\hline 7 & Stream Frequency (Fs) & $\mathrm{Fs}=\mathrm{N} / \mathrm{A}$. Where, $\mathrm{N}=$ Total number of Stream, $\mathrm{A}=$ Area of the Watershed. & Horton 1945 \\
\hline 8 & Texture ratio $(T)$ & $T=N 1 / P$. Where $N 1=$ Total number of first order stream, $p=$ perimeter of watershed & Horton 1945 \\
\hline 9 & Form Factor (Rf) & $\mathrm{Rf}=\mathrm{A} /(\mathrm{Lb})$ 2. Where, $\mathrm{A}=$ Area of the Watershed, $\mathrm{Lb}=$ Maximum Basin length. & Horton 1932 \\
\hline 10 & Circularity Ratio (Rc) & $R C=4 ð A / P 2$. Where, $A=$ Area of the Watershed, $P=$ Perimeter of the basin, $Đ=3.14$ & Strahler 1964a, b \\
\hline 11 & Elongation Ratio (Re) & $\operatorname{Re}=2 \sqrt{ }(A / ð) / L b$. Where, $A=$ Area of the Watershed, $L b=$ Maximum Basin length, $Đ=3.14$. & Schumm 1956 \\
\hline
\end{tabular}

parameter values. The sub-watershed with the lowest compound parameter value was given the highest priority. Accordingly, sub-watersheds are broadly classified into five priority zones based on their compound parameter value $(\mathrm{Cp})$ as, extremely high (8.0-9.9), Very high (10.0-11.9), high (12.0-13.9), moderate (14.0-15.9) and low priority (16.0-17.9) (Farhan and Anaba 2016; Ratnam et al. 2005). Sub- watersheds which consist of steep slopes, high drainage density; high stream frequency, low form factor and low elongation ratio could have less compound value and are classified under very severe flooding susceptibility zone. Thus it needs immediate attention to take soil conservation measures (Kanth and Hassan 2012). Morphometric parameters used for this study were calculated based on the standard formula of morphometric parameters developed by different scholars (Table 2).

Following identification of flood susceptible sub-watersheds, FAO and IMSD guidelines were employed to identify suitable sites where to adopt water conservation technologies. As shown in Table 3, water conservation site identification was conducted using soil, permeability, slope, drainage order and land use (Prinz and Singh 2000; FAO 2003).

\section{Result and discussion Causes of flood hazards}

In Dire Dawa, flash floods are caused by a combination of natural and anthropogenic effects. The survey based collected perceived flood causing factors in Dire Dawa city are depicted in Table 4.

\section{Intense rainfall}

Rainfall is the major factor directly associated with flood hazard of Dire Dawa city. Duration, magnitude and intensity of rainfall determine the formation of flood. The survey result of (Table 4) shows that $92.7 \%$ of respondents agreed that heavy rainfall is the causes for Dawa city flooding. There are three meteorological stations (Dire Dawa, Haramaya, and Dengago) that fall inside the watershed. The meteorological analysis of this study

Table 3 Water conservation site identification criterion

\begin{tabular}{|c|c|c|c|c|c|}
\hline Structure type & Soil & Permeability & LULC & Slope & Drainage \\
\hline Terracing & Sandy clay, clay loam, sandy loam & Medium, high & Bush land and shrub land & $5-30$ & 1st, 2nd order \\
\hline Percolation Tank & Silty loam/ Clay loam & high & Bare/shrub land & $<10$ & $2 \mathrm{nd}, / 3^{\mathrm{rd}} / 4$ th order \\
\hline Pond & $\begin{array}{l}\text { Sandy loam } \\
\text { Silty loam }\end{array}$ & low & shrub & $<5 \%$ & 1st order \\
\hline Check Dam & Sandy clay loam & low & Bare/ shrub & $<15 \%$ & 5th and 6th order \\
\hline Nala bunds & Silty loam & low & Bare/ shrub & $<10$ & $3^{\text {rd }}$ and 4 th order \\
\hline Storage tank & Silty loam, clay & low & Bare & $<30$ & $2 \mathrm{nd}, 1 \mathrm{st}$ and $2 \mathrm{nd}$ order \\
\hline
\end{tabular}


Table 4 Perceived causes of flood hazard in Dire Dawa city

\begin{tabular}{|c|c|c|c|c|c|c|}
\hline \multirow[t]{2}{*}{ Flood causing factors } & \multicolumn{2}{|l|}{ Agree } & \multicolumn{2}{|c|}{ Disagree } & \multicolumn{2}{|c|}{ No response } \\
\hline & Count & $\%$ & Count & $\%$ & Count & $\%$ \\
\hline Intense rainfall & 102 & 92.7 & 0 & 0 & 8 & 7.3 \\
\hline Flood zone occupation & 64 & 58 & 12 & 11 & 34 & 31 \\
\hline Land use change & 83 & 75.5 & 21 & 19 & 6 & 5.5 \\
\hline Topography & 83 & 75.5 & 15 & 13.4 & 12 & 10 \\
\hline Damping of solid waste in river channel & 51 & 46.3 & 54 & 49.1 & 5 & 4.6 \\
\hline Aggravating factors & 77 & 70 & 23 & 21 & 10 & 9 \\
\hline Institutional problem & 15 & 13.5 & 70 & 63.3 & 25 & 22.7 \\
\hline
\end{tabular}

Source: Field survey 2017

shows that (i) flood inducing rainfall is coming from the surrounding highlands located out of Dire Dawa city administration. The records of Dire Dawa meteorological station shows that the station has experienced marked decline of rainfall trend. The slope of rainfall trend analysis show that the rainfall graph for Dire Dawa station shows a negative trend $(\mathrm{Y}=-0.001 \mathrm{x}+60.22)$ and positive trend for Dangago $(\mathrm{Y}=0.040 \mathrm{x}-24.69)$ and Haramaya $(Y=0.0257 x-462.1)$ stations which are located in the upper catchments (Figs. 2, 3, 4). This shows that the effect of rainfall in Dire Dawa station is insignificant to precipitate flood occurrence. Hence, flood causing rainfall is coming from upper catchments of Dangago and Haramaya stations located out of the political boundary of Dire Dawa city.

(ii) Flood of the study area is the result of hourly rainfall variability. The trend analysis of daily rainfall distribution shows that the daily variation of rainfall is not pronounced over the study periods for all stations. More importantly, variations arise from hourly distribution of rainfall plays a significant role. Naturally, rainstorms in the tropics are highly localized, intense, and of short duration, covering less than $10 \mathrm{~km}$ and usually lasting an hour or less (Gupta and Ahmad 1999). The variation of hourly distribution and its effects are depicted in Figs. 4 and 5 for all stations.

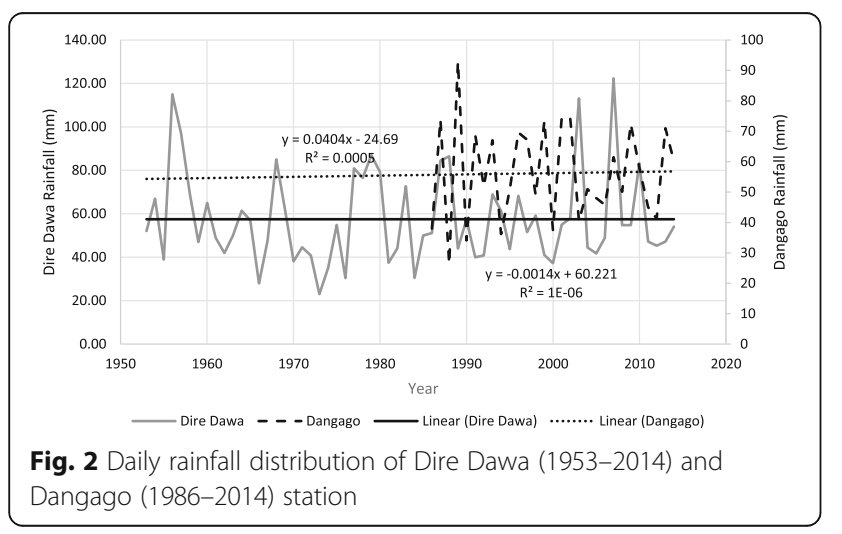

The standardized daily rainfall anomaly shows that sometimes years with highest hourly rainfall could have a declined daily rainfall pattern below mean hourly rainfall records. This confirms that the hourly variation of rainfall distribution that determine the occurrence of flood risk is working independent of hourly, monthly and yearly rainfall distributions. The detailed monthly rainfall analysis of Dire Dawa meteorological station showed that severe and heavy rainfall was recorded in 1956, 1961, 1963, 1964, 1983, 1996 and 2010 at Dire Dawa meteorological stations. The comparison of these higher raining years with historically identified flood event years shows that most of these events have no causative relationship. However, the hourly distribution of extreme rainfall shows that the result is high for the periods identified as flood event years. This confirms that the hourly variation of rainfall distribution of Dire Dawa station is precipitating the cause of flash flood in and around city boundaries. This can be seen by considering the hourly rainfall distribution of 2006 which was known for its devastating flood hazards. For example, the $61 \mathrm{~mm} / \mathrm{hr}$. amount of rainfall recorded in 2006 confirms that the figure represents the highest ever record of hourly rainfall during the study period at all stations (Fig. 5). This implies that the hourly variation of rainfall condition of this station is a potential cause for flood hazards of the city.

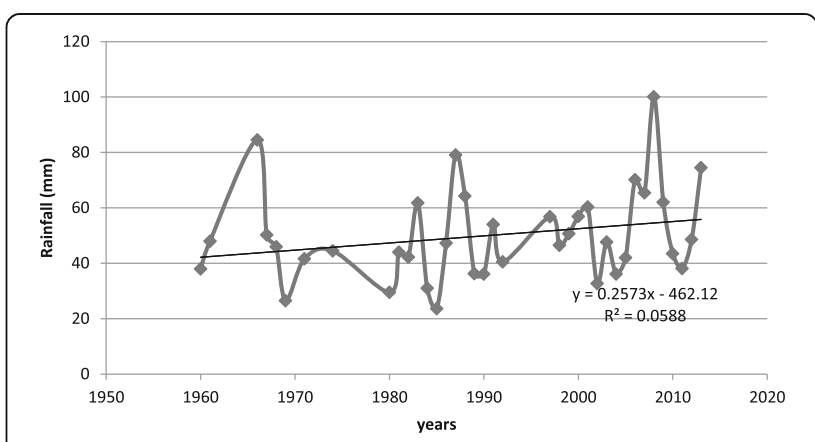

Fig. 3 Daily rainfall distribution of Haramaya station (1960-2013) 


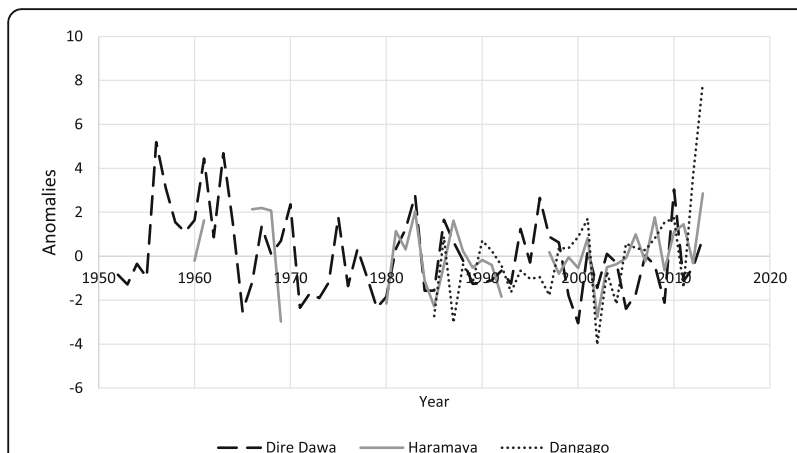

Fig. 4 Standardized daily extreme rainfall anomalies of Dire Dawa, Haramaya and Dangago stations

Similarly, the result of hourly variation of rainfall in other stations complements the scenario of Dire Dawa station that hourly variation of rainfall is causing flood hazard of the study area. The daily trend analysis of rainfall distribution shows that high rainfall were recorded in 1966, 1967,1968,1983, 1987, 2008 and 2013 for Haramaya station and 2001, 2009, 2010, 2012 and 2013 for Dangago station (Figs. 2 and 4). At both stations the high daily rainfall records have no strong relation with identified flood event years. On the Contrary, the maximum hourly rainfall distribution of both stations shows that the hourly distribution result has a relationship with identified flood event years.

Furthermore, the trend analysis result of hourly rainfall data distribution shows that the likelihood of getting more than $30 \mathrm{~mm}$ of hourly maximum rainfall happened every five, four and 3 years cycle for Haramaya, Dire Dawa and Dangago meteorological stations, respectively. The cumulative return period of the three station shows that rainfall affects the city at every 4 years interval. This forecast helps to develop an advance flood mitigation strategies at every forecasted years.

\section{Topography}

Dire Dawa is located on a low land area in the Great East African Rift Valley. Its watershed comprises

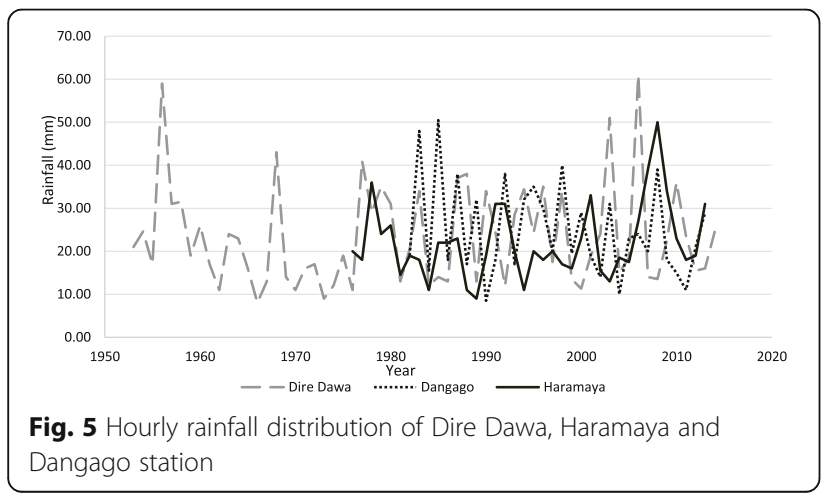

different elevation points that range from 1000 to $2400 \mathrm{~m}$ above sea level. Dire Dawa city, where different rivers meet is the lowest point with an altitude of $1000 \mathrm{~m}$ above sea level. Dangago Mountain, with the peak altitude is located at South of Dire Dawa city in Oromia Regional State. In addition, there are other mountain chains located South of the city that surround the city in Southern direction. These include Kersa, Kulubi and Meta mountains located in the Oromia Regional State boundaries. The location of Dire Dawa at the foot of these mountain chains has exacerbated the flooding of the city complementing with other factors.

\section{Encroachment to river banks}

In most cases, flood damage is the result of exposure. Encroachments to flood river way is the primary exposure causing flood risk in Dire Dawa city. Different types of settlements belonging to individuals, organizations and government institutions have been located inside the original flood path ways. Public institutions such as Medehanalem primary and secondary schools, Addis Ketema secondary school and mosques are among some institutions located in flood prone areas. In the same way, Coca Cola Company has reclaimed inundation areas and filling up the flood zones with polluted wastes released from the company. The interviewed people reported that the effect of flood is changing both in magnitude and damaging capacity with increasing settlements encroaching to flood prone areas. They further explained that the construction of settlements has aggravated flooding problem by reducing width of the river banks. The large informal encroachments of river banks are confined to inner city centers such as Kezera, Dechatu, Ashewa and Bahire Tsige villages. On the other hand, the flood plains of Koka area and Addis ketema have been occupied by formally approved private and government houses. Among the sampled households $58 \%$ of them (Table 4) agreed that the occupation of flood hazard zone is precipitating the cause of flood hazard. Regarding this, one of the elder respondent reported that water never miss its line. He expressed that people have been affected and potentially to be affected if they interfere with the line of the river. People encroach the flood zone for two reasons. Primarily they perceive flood zones as a vacant space and land leftover. Secondly, the rise of urban land price in planned areas pushed low economic classes to settle in hazard zones. As a result greater proportion of migrants prefers to reside in informal way of settlements within the flood zones accompanied by mushrooming of informal settlements.

\section{Waste management factor}

Respondents accounting 46.3\% (Table 4) reported that damping of waste materials in rivers and drainage 


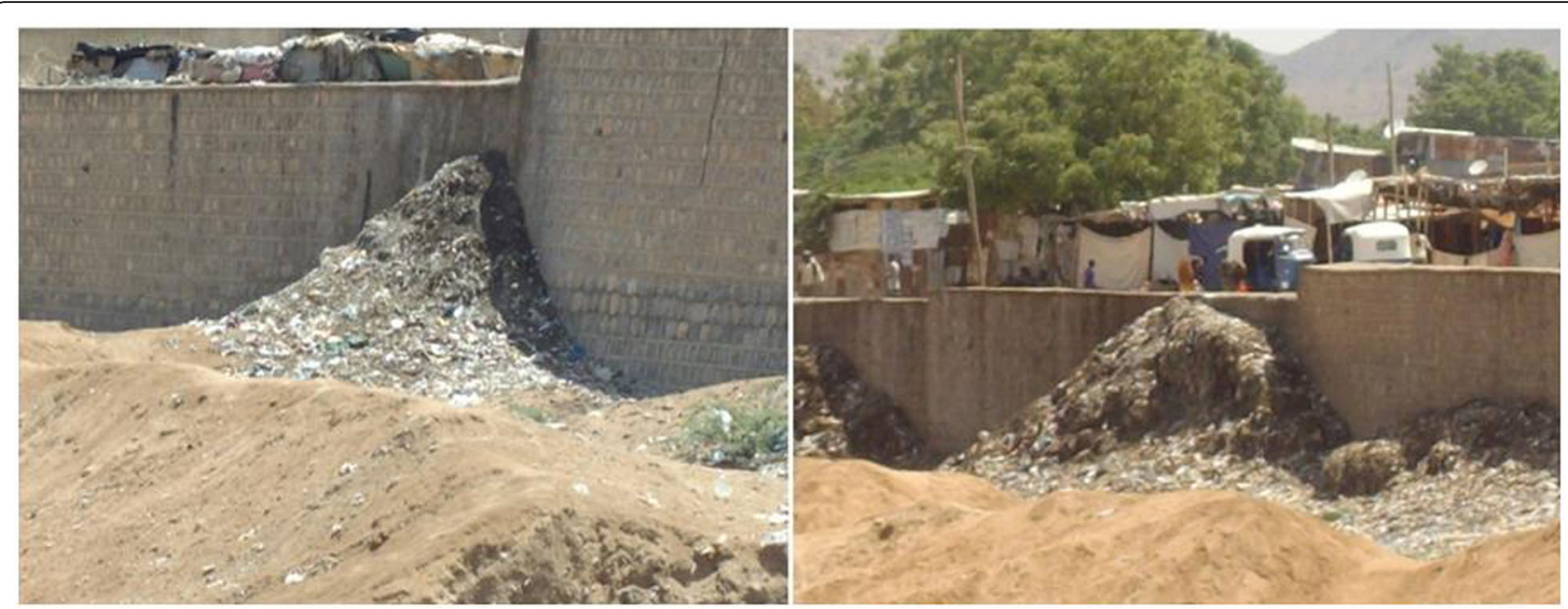

Fig. 6 Solid waste dumped into Dechatu River across the flood protection wall

channels is another factor that exacerbates the flooding problem of Dire Dawa city. Due to the absence of river management policies properly and planned storm water management and waste disposal systems, the city residents of Dire Dawa use river channels as main site of waste disposal areas. As a result, it is common to see the damped wastes in open spaces and river channels. Paradoxically, the largest sizes (49.1\%) of the sample population were unable to associate the causative and effect relationship of poor waste management and flood hazard problem. They disagreed that flood is not an immediate cause of damping of solid waste in to the river channels. However, the existing fact indicated that the damped waste material (Fig. 6) affected the size and the depth of the river channel and disturbing the water velocity.

Complementing with other associated problems, the damped waste is decomposed and helped the growth of vegetation on the banks of the river. For example, drainage line which stretches from the edge of Tonny Agriculture to Gate No.2 of Dire Dawa University (Fig. 7) is almost completely covered with invasive vegetation and blocked by solid wastes and siltation.

\section{Land use change and urban expansion}

Dynamics of population growth and infrastructural development are among major important forces that obliges the expansion of the city. As a result, the city is forced to expand its boundary in all directions including to mountainous and flood prone areas. The expansion of urban area which is accompanied by infrastructural development would be an immediate cause for increase of impervious surface. To explore the land use change and growth direction of Dire Dawa city, the analysis of four decade satellite image was conducted (Table 5).

The overall land use land cover change of the study area shows that the sizes of forest, bush and grass lands

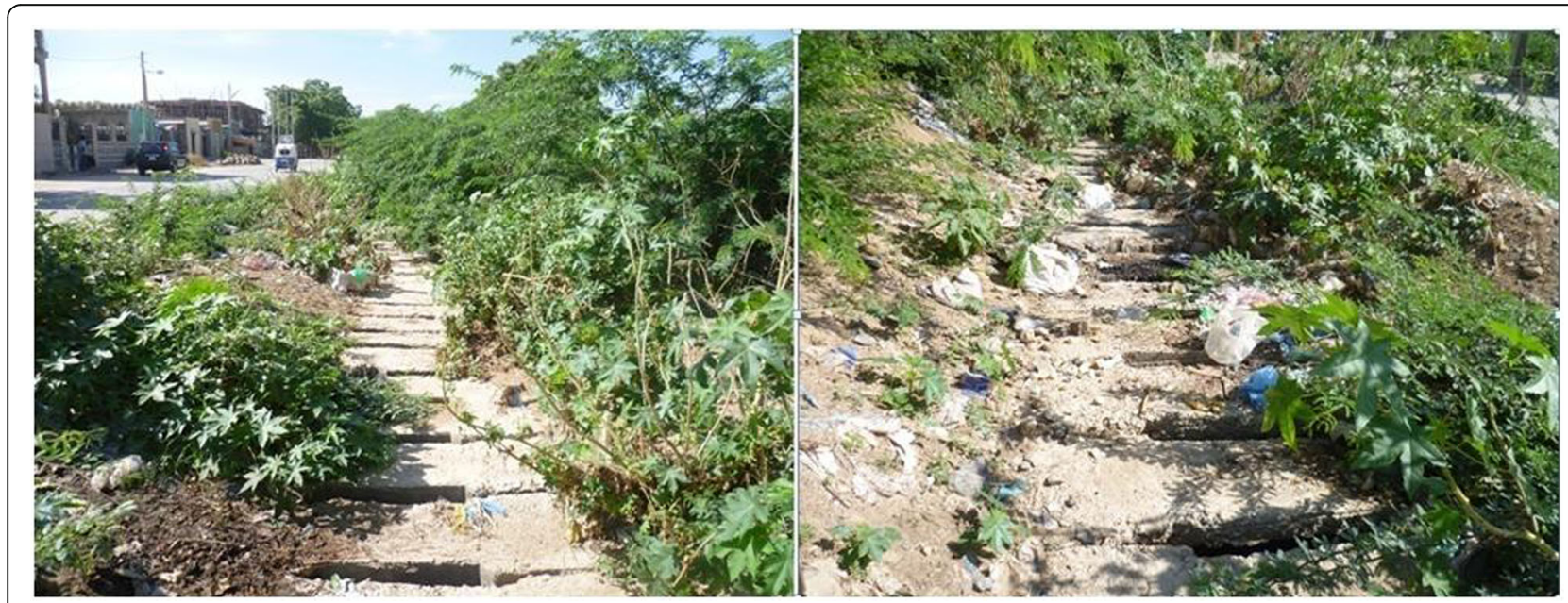

Fig. 7 Vegetated drainage line at Gate no.2 of Dire Dawa University 
Table 5 Land use land cover changes of the watershed

\begin{tabular}{lllll}
\hline Land use $\left(\mathrm{Km}^{2}\right)$ & 1985 & 1995 & 2006 & 2016 \\
\hline Forest & 63.73 & 50.01 & 48.71 & 37.09 \\
Settlements & 17.27 & 27.60 & 30.06 & 44.66 \\
Bush and grass & 345.90 & 316.91 & 282.27 & 236.24 \\
Agriculture & 139.34 & 102.73 & 63.02 & 73.64 \\
Bare land & 115.61 & 171.37 & 261.29 & 308.45 \\
River side & 20.76 & 34.37 & 17.59 & 2.83 \\
\hline
\end{tabular}

are continuously declining over all the study periods. On the contrary settlements and bare land are significantly increasing. This shows that land use land covers that are discouraging flood are consistently decreasing while land use aggravating flood hazard are showing a significant increase.

Regarding urban expansion, the 1985 satellite image analysis shows that Dire Dawa city was confined to the old inner cities of Magala, Kezera and Taiwan villages established during Italian occupation and covers the area of $17.28 \mathrm{Km}^{2}$ (Table 5). Through time the expansion took place in all directions. From 1985 to 1995 the city was expanded mainly to the eastern and southern directions along the foot of the mountains (Fig. 8). During this period the size of the city reached $27.6 \mathrm{~km}^{2}$. During the subsequent decade from (1995 to 2006) all expansions have taken place towards the East and along river side areas which are flood prone zones and left for river buffer. During this decade the size of the city increased to $30 \mathrm{~km}^{2}$. From 2006 to 2016, the city has been expanding in the western directions based on the proposal of the city master plan. The settlement analysis of 2016 satellite imagery shows that the city covered an area of $44.7 \mathrm{Km}^{2}$. The overall Dire Dawa city expansion shows that until 2006 the city has been expanding haphazardly in all directions including to foots of mountain and flood inundation areas. After 2006 western direction is serving as the major site of expansions. This happened because of various reasons. In the first place the 2006 flood damage gave a lesson not to settle in flood sensitive areas. Secondly, the possible expansions to mountain sides are already saturated and no free space for more expansion. Thirdly, the western part is identified to be an expansion site by the municipality. Owing to these facts, it is worth to say that the west ward expansions follows appropriate way of city planning and

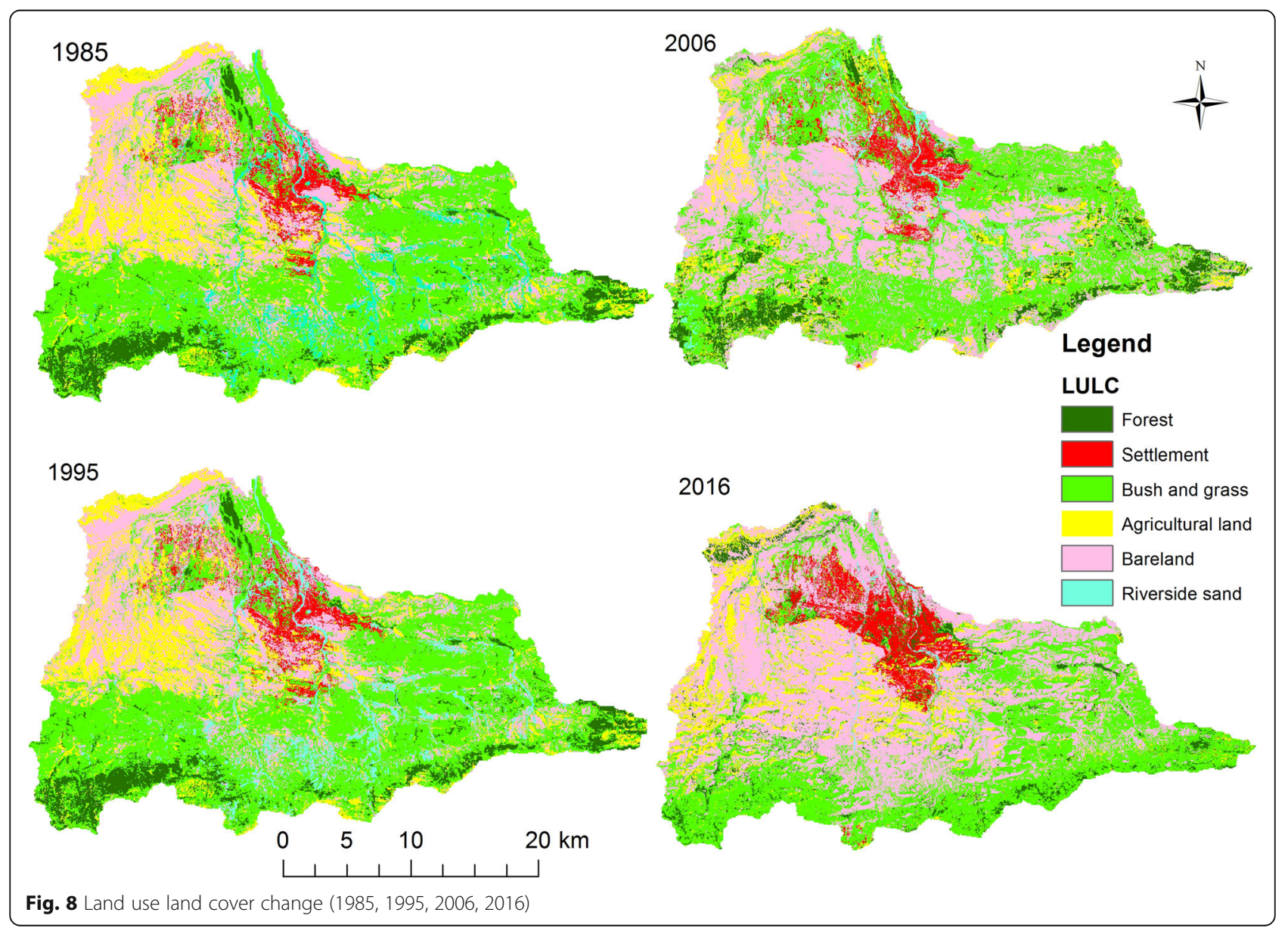


landscape analysis while expansion to the southern and eastern direction followed sprawl and haphazard expansion that result to the occupation of flood hazard zones and unsuitable places for settlement.

\section{Institutional factor}

The lack of strong and trans-regional boundary institutional setup is among the major factors contributed to flood hazard of Dire Dawa city. Due to the geographical location and topography, Dire Dawa city is serving as an outlet for floods coming from different districts of Oromia Regional State. The sources of floods are outside of Dire Dawa administration. The trans-regional nature of floods in Dire Dawa city demands the integration and collaboration of institutions from different regions across political boundaries. The institutional gap in flood management can be seen from different perspective. At the first place, there was no institutional setup that incorporates institutions from different political boundaries. Secondly, there were no intuitions that specifically deal with flood issue neither at city nor at federal levels. Thirdly, even the existing city level institutions are weak in capacity. Therefore, lack of development control exacerbated problems related to unplanned settlements and made the expansion of the city sporadic. The 2006 master plan of Dire Dawa city proposed a minimum river buffer which ranges from 30 to $50 \mathrm{~m}$ for rivers traversing the inner city. Despite the existence of this document, there are various formal and informal ongoing construction activities within the proposed river buffer zones. The ongoing constructions, especially the formally approved private, government and business companies confirm that weakness of existing institution is contributing to flood problem of the city.

\section{Aggravating factors}

Beside the other factor directly causing flood risks, there are numerous factors that exacerbate the level of risks and damages resulted from flooding. Regime change and power interruption during intense rainfall were also reported as major factors aggravating flood induced risks.

Regime change and related land use changes: Land use changes such as inappropriate, misuse and informal occupation of protected areas were affected by political instability. Political transition and regime change allow irresponsible peoples to colonize forests and other buffer zones left for rehabilitation purposes. The continuous forest cutting and colonization of agricultural land particularly on the steep slopes of Dangago and other surrounding mountains was done as result of political vacuum created at different times. According to report from elder respondents, the vegetation cover of the southern highlands of Dangago during the rule of the Emperor (1954-1974) was modestly dense. At that time the forests were owned by landlord that hinders the community to freely access the forest land. Following the collapse of the Imperial rule, massive forests were colonized and destructed by communities. This was happening partly in retaliation to the landlords. In the 1980s, the military government launched a large scale re-afforestation campaign on the upper catchments of Dire Dawa city including Dangago. This campaign had registered significant contribution to the rehabilitation of the degraded environment. However, upon the fall of the military government in 1991, large scale deforestation and human settlement took place within the rehabilitated area especially during transition period (19911995). According to key informants, people illegally settled and secured farmlands on the hilly slopes during this period. As a result, areas which have been a dense forest in the past become devoid of vegetation cover. The information obtained from key informant, former research document and satellite imagery analysis confirms this fact.

Power interruption during heavy rain: Large number of respondents $(70 \%)$ reported that the interruption of power during rainy season has exacerbated the degree of risks and damages caused by flooding. They further indicated that the condition is worst when the rain take place during night time. The city is using a wooden electric pool that can be susceptible to damage with the possibility of causing fire hazard during heavy and windy rainy days. This threatened the Ethiopian Electric Power Corporation (EEPCo) officials to interrupt the power whenever heavy rainfalls take place. The lack of light during night time makes the people not to identify the volume and intensity of the flood. This made the flood to be less understood so that the mobility of the people to rescue their property at expense of their life will occur.

\section{Morphometric analysis of the watershed}

Various morphometric parameters that are attributed to determine the nature of flooding are employed to identify flood susceptible sub-watersheds. These are stream order, stream length, bifurcation ratio, drainage density, texture ratio, form factor, circularity ratio, elongation ratio and compactness constant.

\section{Stream orders}

Dire Dawa city watershed is composed of 26 sub-watersheds. A total of 483 streams were present in the watershed of which 376 belong to 1st order, 87 to 2 nd order, 18 to 3rd order and 2 are 4 th order (Table 6). Higher stream order is associated with greater discharge, and higher velocity (Costa 1987). The 4th order which possibly can generate high discharge and velocity is located at sub-watersheds where Dechatu River is located in the 
Table 6 Stream morphometry analysis

\begin{tabular}{|c|c|c|c|c|c|c|c|c|c|c|c|c|c|}
\hline \multirow[b]{2}{*}{ Watershed } & \multicolumn{4}{|c|}{ No of streams } & \multirow[b]{2}{*}{$\mathrm{Nu}$} & \multicolumn{4}{|c|}{ Stream length (km) } & \multicolumn{4}{|c|}{ Cumulative stream length (km) } \\
\hline & $1 s t$ & 2nd & $3 r d$ & 4 th & & $1 s t$ & 2nd & $3 \mathrm{rd}$ & 4th & $1 s t$ & 2nd & $3 r d$ & 4 th \\
\hline 1 & 3 & 1 & & & 4 & 1.8 & 3.91 & 0.00 & 0.00 & 1.8 & 5.7 & 5.75 & 5.75 \\
\hline 2 & 14 & 3 & 1 & & 18 & 11.5 & 6.49 & 0.81 & 0.00 & 11.5 & 18.0 & 18.79 & 18.79 \\
\hline 3 & 6 & 1 & & & 7 & 2.7 & 0.77 & 0.00 & 0.00 & 2.7 & 3.4 & 3.43 & 3.43 \\
\hline 4 & 36 & 7 & 1 & & 44 & 5.5 & 22.49 & 24.78 & 0.00 & 35.5 & 58.0 & 82.74 & 82.74 \\
\hline 5 & 53 & 13 & 2 & 1 & 69 & 53.9 & 24.55 & 8.05 & 13.97 & 53.9 & 78.4 & 86.50 & 100.47 \\
\hline 6 & 6 & 1 & & & 7 & 3.0 & 1.35 & 0.00 & 0.00 & 3.0 & 4.3 & 4.32 & 4.32 \\
\hline 7 & 19 & 6 & 1 & & 26 & 27.1 & 13.59 & 11.05 & 0.00 & 27.1 & 40.7 & 51.74 & 51.74 \\
\hline 8 & 6 & 2 & 1 & & 9 & 7.6 & 1.76 & 1.43 & 0.00 & 7.6 & 9.3 & 10.75 & 10.75 \\
\hline 9 & 16 & 3 & 1 & & 20 & 12.8 & 3.10 & 14.09 & 0.00 & 12.8 & 15.9 & 30.00 & 30.00 \\
\hline 10 & 21 & 4 & 1 & & 26 & 19.1 & 4.29 & 15.07 & 0.00 & 19.1 & 23.4 & 38.43 & 38.43 \\
\hline 11 & 2 & 1 & & & 3 & 2.6 & 1.78 & 0.00 & 0.00 & 2.6 & 4.4 & 4.41 & 4.41 \\
\hline 12 & 3 & 1 & & & 4 & 3.6 & 4.94 & 0.00 & 0.00 & 3.6 & 8.5 & 8.54 & 8.54 \\
\hline 13 & 10 & 3 & 1 & & 14 & 9.6 & 9.11 & 4.55 & 0.00 & 9.6 & 18.7 & 23.29 & 23.29 \\
\hline 14 & 8 & 1 & & & 9 & 10.0 & 8.25 & 0.00 & 0.00 & 10.0 & 18.2 & 18.24 & 18.24 \\
\hline 15 & 11 & 4 & 1 & & 16 & 5.4 & 4.33 & 7.41 & 0.00 & 5.4 & 9.8 & 17.18 & 17.18 \\
\hline 16 & 7 & 1 & & & 8 & 4.4 & 5.58 & 0.00 & 0.00 & 4.4 & 10.0 & 9.99 & 9.99 \\
\hline 17 & 15 & 4 & 1 & & 20 & 8.5 & 4.09 & 10.33 & 0.00 & 8.5 & 12.5 & 22.87 & 22.87 \\
\hline 18 & 36 & 8 & 1 & & 45 & 32.9 & 17.69 & 18.82 & 0.00 & 32.9 & 50.6 & 69.38 & 69.38 \\
\hline 19 & 22 & 3 & 1 & & 26 & 8.0 & 3.93 & 1.42 & 0.00 & 8.0 & 11.9 & 13.37 & 13.37 \\
\hline 20 & 15 & 5 & 1 & & 21 & 13.8 & 9.35 & 11.23 & 0.00 & 13.8 & 23.2 & 34.41 & 34.41 \\
\hline 21 & 17 & 5 & 2 & 1 & 25 & 19.8 & 6.21 & 2.48 & 6.49 & 19.8 & 26.0 & 28.46 & 34.96 \\
\hline 22 & 21 & 4 & 1 & & 26 & 19.9 & 8.59 & 9.45 & 0.00 & 19.9 & 28.5 & 37.9 & 37.9 \\
\hline 23 & 15 & 3 & 1 & & 19 & 11.8 & 8.30 & 8.07 & 0.00 & 11.8 & 20.1 & 28.2 & 28.2 \\
\hline 24 & 4 & 1 & & & 5 & 6.9 & 5.54 & 0.00 & 0.00 & 6.9 & 12.4 & 12.40 & 12.40 \\
\hline 25 & 8 & 1 & & & 9 & 6.0 & 5.94 & 0.00 & 0.00 & 6.0 & 11.9 & 11.93 & 11.93 \\
\hline 26 & 2 & 1 & & & 3 & 1.3 & 2.43 & 0.00 & 0.00 & 1.3 & 3.7 & 3.74 & 3.74 \\
\hline
\end{tabular}

center of Dire Dawa city (Fig. 9). The distribution of the stream network over the watershed indicates that most of the 1st and 2nd order streams find their origin from surrounding mountainous and hilly areas of Oromia Region (Haramaya, Kersa and Meta) districts where agricultural activity encroaches steep slopes and fragile areas. The location and distribution of 1st order streams confirms that the upper catchment is the primary source of flash flood that affects the whole downstream of the watershed.

\section{Stream length}

Based on the law of Horton (1945), the total stream lengths have an inverse relation with stream order. The law proposed that the total length decreases as stream order increases. The analysis of cumulative stream lengths helps to know the drainage characteristics and movements of the water at different basins (Altaf et al. 2013). Furthermore, the analysis of stream length of individual stream order helps to estimate the amount of discharges traveling to downstream. Higher stream orders (3rd and 4th) are passing through the heart of the city carrying large volume of water collected from the upper catchment and made the risk of flooding very high and challenging to handle. Therefore, it is important to start the management of flooding at upper catchments before the streams join each other to form the high order.

\section{Texture ratio}

Texture ratio $(\mathrm{T})$ represents the total number of stream segments of all orders per unit perimeter of the basin (Rudraiah et al. 2008; Ramaiah et al. 2012). It is governed by lithology, soil, relief, vegetation, infiltration-capacity and climate (Farhan 2017). The lower texture ratio implies the coarser the drainage is while high texture ratio leads to fine drainage texture (Ozdemir and Bird 2009). Based on texture ratio, basins are classified in to different classes (Smith 1950), coarse (2-4), fine (5-8) and very fine $(>8)$ 


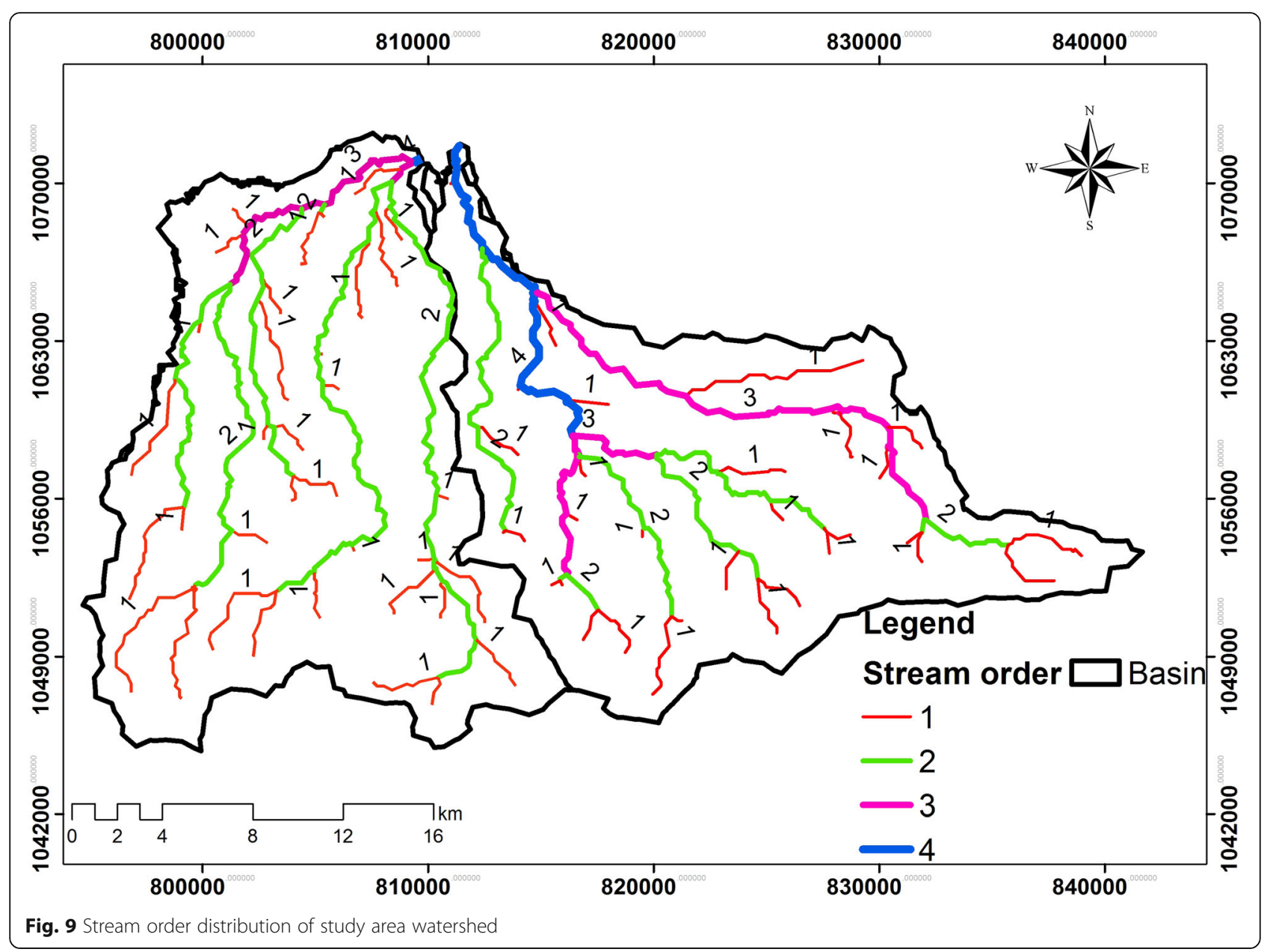

texture ratios. The texture ratio of study area is less than 2 over all the sub-watersheds which show that the whole study area watershed is classified under very course texture that imply high infiltration.

\section{Bifurcation ratio}

Bifurcation ratio $(\mathrm{Rb})$ is the ratio between the numbers of streams of any given order to the number of streams of next higher order. Bifurcation ratio is an important parameter to estimate where flood can take place in the watershed. Basins with higher value of bifurcation ratio are favorite to higher chance of flooding. In a river network with high bifurcation ratio, the outlet receives water from large number of tributaries. The concentration of the waters in to single point increases the volume and intensity of water at the specific river. The mean bifurcation ratio of study area sub-watersheds ranges from 2 to 8 . The value of bifurcation ratio tells about the geologic nature and shape of the watershed (Verstappen 1995; Strahler 1964a, b). When the value of $\mathrm{Rb}$ ranges between 3.0 and 5.0 the rock type is homogeneous, when it is more than 5 , the basin is elongated and geological structure controls the basin (Verstappen 1995; Strahler 1964a, b; Chow 1964). The values of $2 \mathrm{Rb}$ rarely happen and more theoretical. The mean $\mathrm{Rb}$ of the watershed lies between 3 and 5 for sub-watersheds 1,2 , $5,7,9,10,12,13,15,17,20,22,23$, and 24 . This implies that these watersheds have a developed drainage patterns free of geological influence. Higher $\mathrm{Rb}$ was computed for sub-watershed 3, 4, 6, 14, 16, 18, 19 and 25 . This indicates that these watershed experiences elongated shape and mature topography implying lower water infiltration and possibility of flooding. On the contrary, lower $\mathrm{Rb}$ ratio was computed for sub-watersheds 11, 21 and 26 implying less effect of geological structure.

\section{Stream frequency}

Stream frequency is an expression of total number of streams of all orders to total unit area. Stream frequency has direct relationship with flooding. The higher the value of stream frequency is the more erodible the basin. The analysis of stream frequency reflects permeability, infiltration capacity, and relief of watersheds and runoff process (Youssef et al. 2009; Langbein 1947). Stream 
frequency is inversely proportional to infiltration capacity (Altaf et al. 2013). Basins with high stream frequency are characterized by low infiltration capacities. The stream frequency analysis of study area shows that the value of stream frequency is relatively higher for sub-watershed 19, 3 and 26, respectively (Table 7). The result of this study shows that, the highest stream frequency occurs at the final outlet of the watersheds located at the extremely downstream of Dire Dawa city where flood problem is more severe.

\section{Drainage density}

Drainage density (Dd) is the total length of all streams per unit area. It expresses the closeness of spacing of streams and drainage efficiency of the watershed (Horton 1932). Like other linear parameters drainage density has a direct relationship with flooding. It is governed by various factors affecting surface runoff such as climate, vegetation cover, soil, rock properties and so on (Moglen et al. 1998; Altaf et al. 2013). The higher the value of Dd is the higher the risk of flooding and vice versa. Conversely, basins with low and moderate Dd are composed of permeable surface, good vegetation cover, and low relief that results to more infiltration capacity and good site for ground water recharge (Altaf et al. 2013). In the study area sub-watershed 19 has maximum Dd (2.44) while sub-watershed 1 has a minimum Dd (0.54). The overall Dd of study area ranges between 0.54 and 2.44 indicating that the study area watershed is characterized by low drainage density. This shows that even though other factors are inflicting flooding, the study area watershed is favorable to establish water recharge sites that help to mitigate the causes of flooding.

\section{Elongation ratio}

Elongation ratio ( $\mathrm{Re})$ is used to assess the shape of the basin which can tell about the flooding condition of the basin. Basins with higher elongation ratio are tending to

Table 7 Watershed parameter analysis

\begin{tabular}{|c|c|c|c|c|c|}
\hline Watershed & Area $\left(\mathrm{km}^{2}\right)$ & Perimeter $(\mathrm{km})$ & Basin length $(\mathrm{km})$ & Drainage density $\left(\mathrm{Km} / \mathrm{km}^{2}\right)$ & stream frequency \\
\hline 1 & 10.7 & 22.6 & 5.04 & 0.54 & 0.37 \\
\hline 2 & 17.9 & 38.8 & 6.75 & 1.05 & 1.01 \\
\hline 3 & 3.6 & 16.4 & 2.72 & 0.95 & 1.94 \\
\hline 4 & 77.8 & 92.5 & 15.56 & 1.06 & 0.57 \\
\hline 5 & 95.7 & 97.3 & 17.50 & 1.05 & 0.72 \\
\hline 6 & 7.7 & 18.8 & 4.18 & 0.56 & 0.91 \\
\hline 7 & 44.6 & 53.3 & 11.35 & 1.16 & 0.58 \\
\hline 8 & 10.5 & 22.6 & 5.00 & 1.02 & 0.85 \\
\hline 9 & 29.6 & 56.5 & 8.98 & 1.01 & 0.68 \\
\hline 10 & 39.3 & 51.8 & 10.60 & 0.98 & 0.66 \\
\hline 11 & 3.7 & 17.9 & 2.76 & 1.19 & 0.81 \\
\hline 12 & 6.6 & 24.0 & 3.84 & 1.29 & 0.60 \\
\hline 13 & 21.1 & 32.8 & 7.42 & 1.10 & 0.66 \\
\hline 14 & 17.8 & 30.9 & 6.72 & 1.03 & 0.51 \\
\hline 15 & 20.4 & 31.9 & 7.28 & 0.84 & 0.78 \\
\hline 16 & 10.4 & 21.4 & 4.97 & 0.96 & 0.77 \\
\hline 17 & 25.7 & 39.5 & 8.30 & 0.89 & 0.78 \\
\hline 18 & 78.1 & 69.9 & 15.59 & 0.89 & 0.58 \\
\hline 19 & 5.5 & 15.1 & 3.45 & 2.44 & 4.74 \\
\hline 20 & 39.2 & 42.1 & 10.55 & 0.88 & 0.54 \\
\hline 21 & 33.8 & 39.5 & 9.69 & 1.03 & 0.74 \\
\hline 22 & 38.3 & 47.5 & 10.41 & 0.99 & 0.68 \\
\hline 23 & 30.4 & 39.1 & 9.12 & 0.93 & 0.63 \\
\hline 24 & 13.3 & 27.0 & 8.54 & 0.93 & 0.38 \\
\hline 25 & 14.3 & 24.6 & 5.94 & 0.84 & 0.63 \\
\hline 26 & 2.4 & 13.8 & 2.14 & 1.58 & 1.27 \\
\hline
\end{tabular}


have high infiltration capacity and low runoff. Under varieties of climate condition and geologic type, the value of elongation ratio lies between 0.6 to 1 (Dar et al. 2013). A basin with elongation values close to 1 are basins with very low relief and termed as a circular basin, whereas basins with elongation ratio of 0.6 to 0.8 are classified as high relief and steep slopes with oval shape Strahler (1964a, b).Basins with elongation ratio less than 0.6 are called elongated with high relief and ground slopes (Ali and Ahmad 2014). A circular basin produces less discharge and runoff compared to the oval and elongated basin (Singh and Singh 1997). In the study area the elongation ratio ranges from 0.6 to 0.810 except for sub-watershed 24 with $\mathrm{Re}$ of 0.48 (Table 8). This indicates that the whole watershed is elongated in shape implying low infiltration capacity that leads to high soil erosion which induces flash flooding.

\section{Circulatory ratio (Rc)}

Circularity ratio expresses basin shape, rate of infiltration and the time needed for excess water to reach the basin outlet. $R_{c}$ is expressed as the area of the basin to the area of a circle having the same circumference as the perimeter of the basin (Miller 1953). Low, medium, and high values of $R_{c}$ denote young, mature, and old stages of the geomorphic cycle of the catchment, respectively (Farhan and Ayed 2017). Higher $R_{c}$ shows that the basin could have delayed time to peak flow while the lower value shows shorter time to peak. Circulatory ratio of the study area (Table 8) varies from 0.1 (sub-watershed 4) to 0.3 (sub-watershed 19). The result of $R_{c}$ shows that all sub-watersheds are elongated in shape indicating that the basins are characterized by elongated shape with low infiltration and high relief that can cause flood risks. As mitigation strategy, elongated watershed gives a chance to reduce the water velocity through construction of

Table 8 Morphometric parameter analysis

\begin{tabular}{|c|c|c|c|c|c|c|c|c|c|}
\hline \multirow[b]{2}{*}{ Watershed } & \multirow[b]{2}{*}{ Rc } & \multirow[b]{2}{*}{$\operatorname{Re}$} & \multirow[b]{2}{*}{$\mathrm{Rf}$} & \multirow[b]{2}{*}{$T$} & \multirow[b]{2}{*}{ Cc } & \multicolumn{4}{|c|}{ Bifurcation ratio $(\mathrm{Rb})$} \\
\hline & & & & & & 1 to 2 & 2 to 3 & 3 to 4 & Mean $\mathrm{Rb}$ \\
\hline 1 & 0.26 & 0.73 & 0.42 & 0.18 & 1.94 & 3.0 & & & 3.0 \\
\hline 2 & 0.15 & 0.71 & 0.39 & 0.46 & 2.59 & 4.7 & 3 & & 3.8 \\
\hline 3 & 0.17 & 0.79 & 0.49 & 0.43 & 2.43 & 6.0 & & & 6.0 \\
\hline 4 & 0.11 & 0.64 & 0.32 & 0.48 & 2.96 & 5.1 & 7 & & 6.1 \\
\hline 5 & 0.13 & 0.63 & 0.31 & 0.71 & 2.81 & 4.1 & 6.5 & 2 & 4.2 \\
\hline 6 & 0.27 & 0.75 & 0.44 & 0.37 & 1.92 & 6.0 & & & 6.0 \\
\hline 7 & 0.20 & 0.66 & 0.35 & 0.49 & 2.25 & 3.2 & 6 & & 4.6 \\
\hline 8 & 0.26 & 0.73 & 0.42 & 0.40 & 1.96 & 3.0 & 2 & & 2.5 \\
\hline 9 & 0.12 & 0.68 & 0.37 & 0.35 & 2.93 & 5.3 & 3 & & 4.2 \\
\hline 10 & 0.18 & 0.67 & 0.35 & 0.50 & 2.33 & 5.3 & 4 & & 4.6 \\
\hline 11 & 0.15 & 0.79 & 0.49 & 0.17 & 2.62 & 2.0 & & & 2.0 \\
\hline 12 & 0.14 & 0.76 & 0.45 & 0.17 & 2.63 & 3.0 & & & 3.0 \\
\hline 13 & 0.25 & 0.70 & 0.38 & 0.43 & 2.01 & 3.3 & 3 & & 3.2 \\
\hline 14 & 0.23 & 0.71 & 0.39 & 0.29 & 2.07 & 8.0 & & & 8.0 \\
\hline 15 & 0.25 & 0.70 & 0.39 & 0.50 & 1.99 & 2.8 & 4 & & 3.4 \\
\hline 16 & 0.29 & 0.73 & 0.42 & 0.37 & 1.87 & 7.0 & & & 7.0 \\
\hline 17 & 0.21 & 0.69 & 0.37 & 0.51 & 2.20 & 3.8 & 4 & & 3.9 \\
\hline 18 & 0.20 & 0.64 & 0.32 & 0.64 & 2.23 & 4.5 & 8 & & 6.3 \\
\hline 19 & 0.30 & 0.77 & 0.46 & 1.72 & 1.82 & 7.3 & 3 & & 5.2 \\
\hline 20 & 0.28 & 0.67 & 0.35 & 0.50 & 1.90 & 3.0 & 5 & & 4.0 \\
\hline 21 & 0.27 & 0.68 & 0.36 & 0.63 & 1.92 & 3.4 & 2.5 & 2 & 2.6 \\
\hline 22 & 0.21 & 0.67 & 0.35 & 0.55 & 2.17 & 5.3 & 4 & & 4.6 \\
\hline 23 & 0.25 & 0.68 & 0.37 & 0.49 & 2.00 & 5.0 & 3 & & 4.0 \\
\hline 24 & 0.23 & 0.48 & 0.18 & 0.18 & 2.09 & 4.0 & & & 4.0 \\
\hline 25 & 0.30 & 0.72 & 0.40 & 0.37 & 1.84 & 8.0 & & & 8.0 \\
\hline 26 & 0.16 & 0.81 & 0.52 & 0.22 & 2.53 & 2.0 & & & 2.0 \\
\hline
\end{tabular}


water harvesting structures such as dams and surface reservoirs.

\section{Form factor (Rf)}

Form factor is used to forecast the flow intensity of a given basin (Horton 1945). The value of form factor parameter is directly proportional to flooding. Basins with high form factors tend to face low flood risks while basins with low form factors are highly susceptible to flooding. The computed value of form factor of the study area lies between 0.3 and 0.52 (Table 8). This articulates that all sub-watersheds are elongated in shape and are susceptible to flooding.

\section{Compactness constant (cc)}

A perfectly circular shape watershed could have high compactness constant that implies that the basin experiences high infiltration. Watershed with less compactness constant is susceptible to flooding. The computed value of Cc of the study area shows that sub-watershed 4 has a maximum value 2.96 while sub-watershed 19 has a minimum value 1.82. This shows that most of the sub-watersheds are not circular in shape and hence susceptible to flooding.

\section{Prioritization of sub-watersheds for conservation activities} Conservation activity demands resource, manpower and time. Taking into consideration these factors, it is not possible to take the conservation of the whole area at a time. At the same time, all sub-watersheds are not equally exposed to flooding. Hence prioritizing the sub-watershed is the precondition to implement conservation activities. The prioritization of the sub-watershed was determined based on linear and shape parameters of morphometric analysis. The morphometric result based rank of sub-watershed was depicted in Table 9 and Fig. 10.

Based on compound parameter result of morphometric analysis, the study area sub-watersheds (SW) are classified in to five categories. The sub-watersheds with the least $\mathrm{CP}$ are ranked as the most flood vulnerable area that demands urgent intervention for conservation. The next prioritization also follows the same trend. Accordingly, SW-5 and SWS-18 fall in the highest priority, SW-4, SW-7, SW-10, SW-20 and SW-22 fall in very high priority and SW-9, SW-13, SW-14, SW-15, SW-16, SW-17, SW-19, SW-21, SW-23 and SW-25 fall in the high priority category. These sub-watersheds demand conservation measures on the basis of their priority category. The SW-2, SW-3, SW-6, SW-8 and SW-24 fall in the moderate priority. Sub-watershed 1, 11, 12, and 26 fall in the low priority category and classified as sites free of flood threat (Fig. 10).
Table 9 Prioritization of watershed based morphometric analysis results

\begin{tabular}{lllllllllll}
\hline Watershed & $\mathrm{Rbm}$ & $\mathrm{Dd}$ & $\mathrm{Fs}$ & $\mathrm{T}$ & $\mathrm{Rf}$ & $\mathrm{Rc}$ & $\mathrm{Cc}$ & $\mathrm{Re}$ & $\mathrm{CP}$ & $\mathrm{Rank}$ \\
\hline 1 & 21 & 18 & 26 & 24 & 1 & 20.0 & 7 & 18 & 16.875 & 23 \\
2 & 18 & 14 & 4 & 13 & 24 & 6.0 & 21 & 15 & 14.375 & 18 \\
3 & 6 & 25 & 2 & 14 & 25 & 8.0 & 19 & 25 & 15.5 & 20 \\
4 & 5 & 3 & 22 & 12 & 10 & 1.0 & 26 & 4 & 10.375 & 3 \\
5 & 12 & 1 & 12 & 2 & 22 & 3.0 & 24 & 2 & 9.75 & 2 \\
6 & 6 & 21 & 5 & 18 & 20 & 22.0 & 5 & 21 & 14.75 & 19 \\
7 & 11 & 4 & 20 & 10 & 7 & 10.0 & 17 & 5 & 10.5 & 4 \\
8 & 24 & 19 & 6 & 16 & 16 & 19.0 & 8 & 19 & 15.875 & 22 \\
9 & 13 & 10 & 14 & 20 & 13 & 2.0 & 25 & 11 & 13.5 & 14 \\
10 & 9 & 5 & 16 & 8 & 14 & 9.0 & 18 & 6 & 10.625 & 6 \\
11 & 25 & 24 & 7 & 25 & 6 & 5.0 & 22 & 24 & 17.25 & 24 \\
12 & 21 & 22 & 19 & 26 & 3 & 4.0 & 23 & 22 & 17.5 & 25 \\
13 & 20 & 12 & 15 & 15 & 9 & 16.0 & 11 & 13 & 13.875 & 17 \\
14 & 1 & 15 & 24 & 21 & 2 & 15.0 & 12 & 16 & 13.25 & 13 \\
15 & 19 & 13 & 8 & 7 & 17 & 18.0 & 9 & 14 & 13.125 & 12 \\
16 & 3 & 20 & 10 & 17 & 12 & 24.0 & 3 & 20 & 13.625 & 15 \\
17 & 17 & 11 & 9 & 6 & 21 & 12.0 & 15 & 12 & 12.875 & 11 \\
18 & 4 & 2 & 21 & 3 & 11 & 11.0 & 16 & 3 & 8.875 & 1 \\
19 & 8 & 23 & 1 & 1 & 26 & 26.0 & 1 & 23 & 13.625 & 15 \\
20 & 14 & 6 & 23 & 9 & 4 & 23.0 & 4 & 7 & 11.25 & 7 \\
21 & 23 & 8 & 11 & 4 & 19 & 21.0 & 6 & 9 & 12.625 & 9 \\
22 & 9 & 7 & 13 & 5 & 15 & 13.0 & 14 & 8 & 10.5 & 4 \\
23 & 14 & 9 & 18 & 11 & 8 & 17.0 & 10 & 10 & 12.125 & 8 \\
24 & 14 & 17 & 25 & 23 & 18 & 14.0 & 13 & 1 & 15.625 & 21 \\
25 & 1 & 16 & 17 & 19 & 5 & 25.0 & 2 & 17 & 12.75 & 10 \\
26 & 25 & 26 & 3 & 22 & 23 & 7.0 & 20 & 26 & 19 & 26 \\
\hline & & & & & & & & & \\
19 & 19 & 19 & &
\end{tabular}

\section{Water conservation site identification}

The result of previous study shows that morphometric parameters of the study area are elongated in shape and less controlled by structural condition Girma and Bhole (2015). This shows that landscape based strategy is more important to fully the curb problem of flooding in the study area. To minimize the effect of flooding, different sites were identified for different water conservation mechanisms using soil, permeability, slope, land use and stream conditions of sub-watersheds. Accordingly, 6257 ha were proposed for terracing activities. In the same way 36 sites were identified for construction of ponds, 19 for percolation tanks, 9 for storage tanks, 8 for nala bunds and 5 sites for check dams. These sites were identified using soil, permeability, slope, land use land cover and stream orders and by combining these overlays with flood sensitive sub-watershed generated from morphometric parameters. As shown in Fig. 11, most of the locations proposed for water and soil 


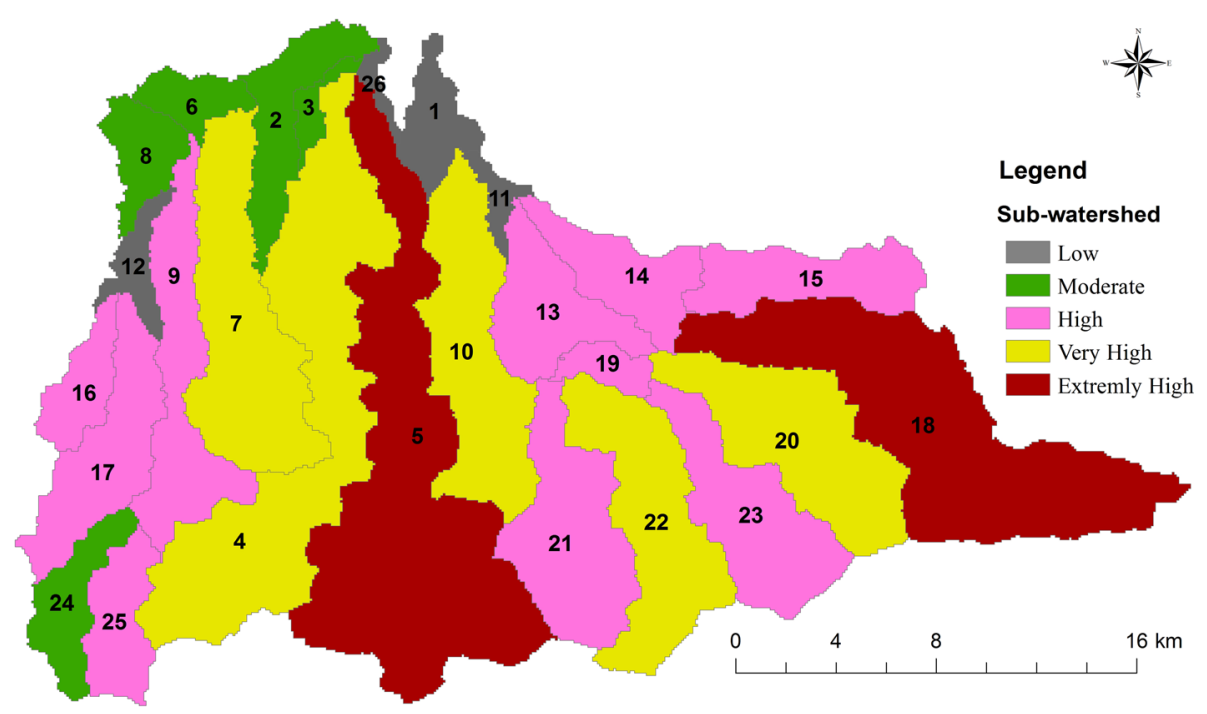

Fig. 10 Map of Prioritized sub-watersheds

conservation activities are located at upper catchments out of the city boundary. For example, many percolation tanks are proposed at one of the most flood vulnerable site (SW-18) of upper catchments, while least is proposed for the SW-5 which is located within the urban boundary. This is to show that most of the sources are coming from upper catchments. AS major areas of SW-5 are located in urban boundaries less percolation tanks were proposed at dawn streams of this sub-watershed. In general the location of conservation measures confirms that effective utilization of proposed structures at proposed site can

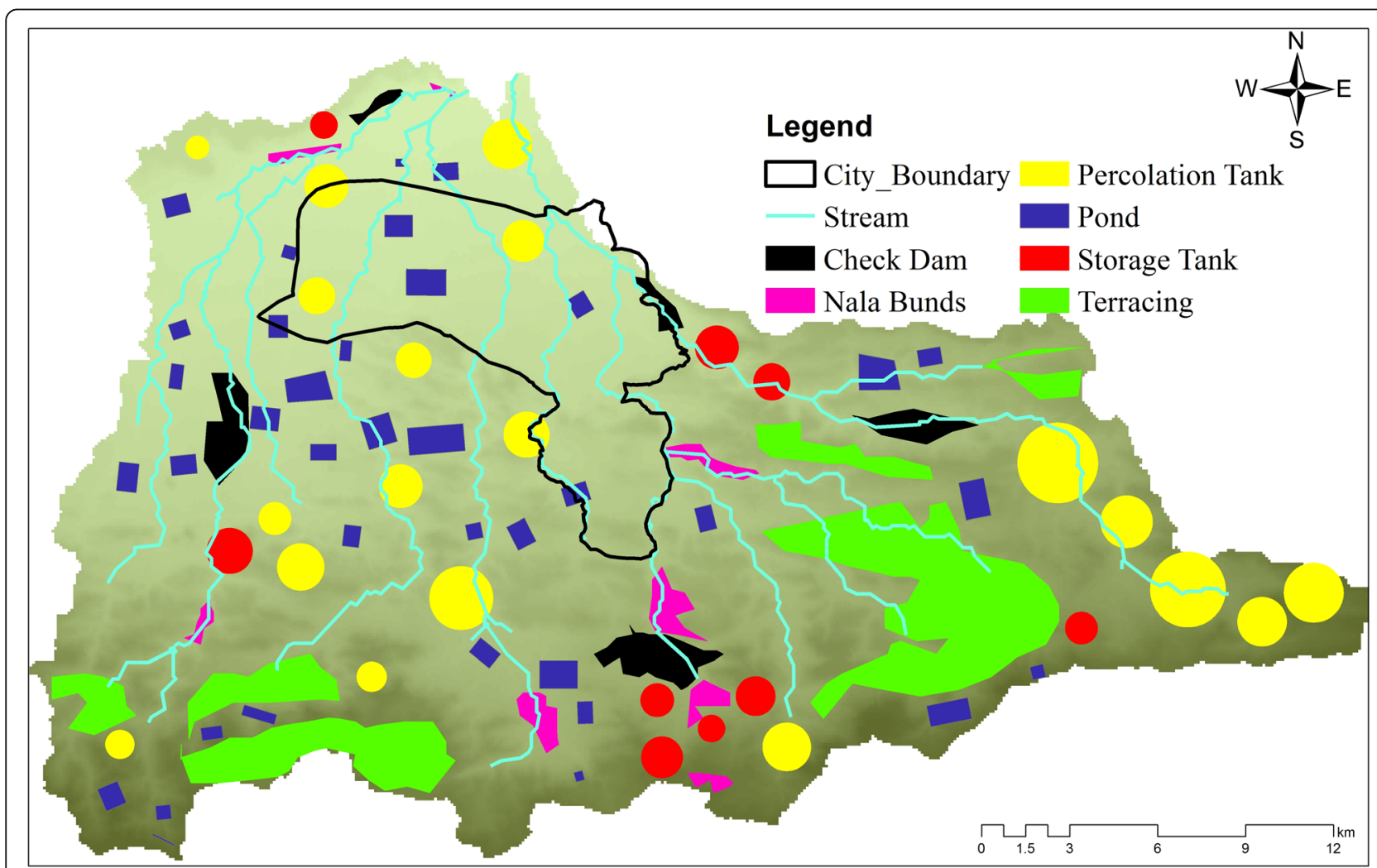

Fig. 11 Proposed map of water conservation sites 
significantly minimize the amount of flood water entering the city boundaries.

\section{Conclusion}

This study was conducted to assess the causes of flood risk and to propose landscape-based flood mitigation strategies. The causes of flood were analyzed from meteorological, institutional, anthropogenic and physical factors perspectives. Questionnaire based data, meteorological record, satellite image and GIS based morphometry analysis were used to assess the causes of flood risk in the study area. The findings of the study shows that flood risk in Dire Dawa city is caused by multiple factors such as rainfall variability, intense rainfall at the surrounding mountains, solid waste damping in the river channels, encroachment of settlements to the river banks, institutional problem, land use land cover change and topography. These causes are fuelled by aggravating factors such as regime change and power interruption. Most importantly, the study area flooding was attributed to hourly rainfall variability. Following the comprehensive assessment of causes of flood risk, sub-watersheds' susceptibility to flood risk was analyzed. Accordingly, the watershed was divided in to 26 mini sub-watersheds. The quantification of each sub-watershed was carried out using morphometric parameters such as linear aspects including Stream order $(\mathrm{Nu})$, Bifurcation ratio $(\mathrm{Rb})$, drainage density $(D \mathrm{~d})$, stream frequency $(\mathrm{Fs})$,texture ratio $(\mathrm{T})$ and shape aspects such as, form factor $(R \mathrm{f})$, circulatory ratio $(R c)$, and elongation ratio $(R \mathrm{e})$ and compactness constant $(\mathrm{Cc})$. Higher values of linear parameter and lower values of shape parameters were attributed to high flood risk. The results of these parameters enabled to categorized sub-watersheds in to five classes, extremely high, very high, high, moderate and low flood susceptible zones. Based on these classes, sub-watersheds were prioritized for conservation activities. The overall results of morphometric analysis shows that managing the root causes of flooding at upper catchments can minimize the volume and intensity of flood causing water before it enters the city boundary. Finally, site selection for water conservation was carried out using soil, permeability, slope, land use land cover and stream orders and by combining these overlays with classes generated from morphometric parameters. Accordingly, different sites were proposed for landscape based flood mitigation measures such as construction of terracing, check dam, percolation tank, storage tank, nala bunds and ponds. To fully curb the problem of flooding, it is highly recommended that the proposed water conservation structures should be adopted as one of the components of sustainable flood risk management strategies in Dire Dawa city and its surroundings.

\section{Acknowledgements}

We are pleased to thank DAAD in country/ in Region scholarship for East Africa and thematic area research fund (Addis Ababa University) for funding this study.

\section{Funding}

The data collection and field work cost was funded by thematic area research obtained from Addis Ababa university.

\section{Availability of data and materials}

The data sets supporting the analysis of this article are included in the body of the paper.

\section{Authors' contributions}

The corresponding author, SHE is a senior lecturer in the School of Geography and Environmental studies, Haramaya University. He collected data and drafted the manuscript. HW, is a Professor of Urban Environmental planning at Ethiopian Institute of Architecture Building Construction and City Development (EiABC), Addis Ababa University. He supervised the study and reviewed the whole content. Both authors contributed for the preparation of the manuscript and deserve to be an author of the study. Both authors read and approved the final manuscript.

\section{Competing interests}

The authors declare that they have no competing interests.

\section{Publisher's Note}

Springer Nature remains neutral with regard to jurisdictional claims in published maps and institutional affiliations.

\section{Author details}

${ }^{1}$ School of Geography and Environmental Studies, Haramaya University, Dire Dawa, Ethiopia. ${ }^{2}$ Ethiopian Institute of Architecture Building Construction and City Development, Addis Ababa University, Addis Ababa, Ethiopia.

Received: 1 May 2018 Accepted: 9 October 2018

Published online: 19 October 2018

\section{References}

Abrahams, A.D. 1984. Channel networks: A geomorphological perspective. Water Resource Research 20: 161-168.

Agarwal, R., P.K. Garg, and R.D. Garg. 2013. Remote sensing and GIS based approach for identification of artificial recharge sites. Water Resource Management 27 (7): 2671-2689. https://doi.org/10.1007/s11269-013-0310-7.

Agbola, S.B., O. Ajayi, J.O. Taiwo, and W.B. Wahab. 2012. The august 2011 flood in Ibadan, Nigeria: Anthropogenic causes and consequences. International Journal of Disaster Risk Science 3 (4): 207-217.

Al-Adamat, R., S. AlAyyash, H. Al-Amoush, O. Al-Meshan, Z. Rawajfih, A. Shdeifat, and M. Al-Farajat. 2012. The combination of indigenous knowledge and geoinformatics for water harvesting sitting in the Jordanian Badia. Journal of Geographic Information System 4: 366-376.

Alemayehu, D. 2007. Assessment of flood risk in Dire Dawa town, Eastern Ethiopia, Using GIS. Ethiopia: Unpublished Msc. Thesis, Addis Ababa University.

Ali, U., and A. Ahmad. 2014. Analysis of drainage morphometry and watershed prioritization of Romushi - Sasar catchment, Kashmir Valley, India using remote sensing and GIS technology. International Journal of Advanced Research 2 (12): 5-23.

Altaf, F., G. Meraj, and S. Romshoo. 2013. Morphometric analysis to infer hydrological behavior of Lidder watershed, Western Himalaya, India. Geography Journal: 13, 1-13,14.

Ammar, Adham, Michel Riksen, Mohamed Ouessar, and Coen Ritsema. 2016. Identification of suitable sites for rainwater harvesting structures in arid and semi-arid regions: A review. International Soil and Water Conservation Research 4 (2): 108-120 https://doi.org/10.1016/j.iswcr.2016.03.001.

Bouwer, L.M. 2013. Projections of future extreme weather losses under changes in climate and exposure. Risk Analysis 33: 915-930.

Chandniha, S.K., and M.L. Kansal. 2017. Prioritization of sub-watersheds based on morphometric analysis using geospatial technique in Piperiya watershed, India. Applied Water Science 7 (1): 329-338.

Chow, V.T. 1964. Handbook of applied hydrology: A compendium of water-resources technology, 1495. New York: McGraw-Hill. 
Chowdary, V.M., D. Chakraborthy, A. Jeyaram, Y.V.N.K. Murthy, J.R. Sharma, and V.K. Dadhwal. 2013. Multi-criteria decision making approach for watershed prioritization using analytic hierarchy process technique and GIS. Water Resources Management 27 (10): 3555-3571. https://doi.org/10.1007/s11269-013-0364-6.

Costa, J.E. 1987. Hydraulics and basin morphometry of the largest flash floods in the conterminous United States. Journal of Hydrology 93 (34): 313-338.

CSA. 2013. Population Projection of Ethiopia for all Regions at Woreda level from 2014-2017, Central Statistical Authority, Addis Ababa.

Dar, R.A., R. Chandra, and S.A. Romshoo. 2013. Morphotectonic and Lithostratigraphic analysis of Intermontane Karewa basin of Kashmir Himalayas, India. Journal of Mountain Science 10 (1): 1-15.

Dawod, G.M., M.N. Mirza, and K.A. Al-Ghamdi. 2012. GIS-based estimation of flood hazard impacts on road network in Makkah city, Saudi Arabia. Environmental Earth Science 67 (8): 2205-2215 https://doi.org/10.1007/s12665-012-1660-9.

Doocy S, Daniels A, Murray S, Kirsch TD.2013. The human impact of floods: A historical review of events 1980-2009 and systematic literature review. PLOS currents disasters. Edition 1.

Eze, E.B., and J. Efiong. 2010. Morphometric parameters of the Calabar river basin: Implication for hydrologic processes. Journal of Geography and Geology 2 (1): $18-26$.

FAO. 1998. Irrigation and Drainage, No 56, FAO, Rome, Italy.

FAO. 2003. Land and water digital media series, 26. Training course on RWH (CDROM). Planning of water harvesting schemes, unit 22. Rome: Food and Agriculture Organization of the United Nations, FAO.

Farhan, Y. 2017. Morphometric assessment of Wadi Wala watershed, southern Jordan using ASTER (DEM) and GIS. Journal of Geographic Information System 9: 158-190.

Farhan, Y., and O. Anaba. 2016. Remote sensing and GIS approach for prioritization of Wadi Shueib mini-watersheds (Central Jordan) based on morphometric and soil erosion susceptibility analysis. Journal of Geographical Information System 8: 1-19.

Farhan, Y., and A. Ayed. 2017. Assessment of flash-flood Hazard in arid watersheds of Jordan. Journal of Geographic Information System 9: 717751.

Funk, T. 2006. Heavy convective rainfall forecasting: A look at elevated convection, propagation and precipitation efficiency. In In proceedings of the 10th severe storm and Doppler radar conference. Des Moines, IA: National Weather Association.

Gardiner, V. 1990. Drainage basin morphometry. In Geomorphological techniques, ed. A.S. Goudie, 71-81. London: Unwin Hyman.

Girma, M., and V. Bhole. 2015. Morphometric characteristics and the relation of stream orders to hydraulic parameters of river Goro: An Ephemeral River in Dire-Dawa, Ethiopia. Universal Journal of Geoscience 3 (1): 13-27.

Gupta, A., and R. Ahmad. 1999. Geomorphology and the UrbanTropics: Building an Interface between research and usage. Geomorphology 31 (1-4): 133-149.

Horton, R.E. 1932. Drainage basin characteristics. Transactions of American Geophysical Union 13: 350-361.

Horton, R.E. 1945. Erosional development of streams and their drainage basins: Hydro-physical approach to quantitative morphology. Geological Society of American Bulletin 5: 275-370.

International Strategy for Disaster Reduction (ISDR). 2008. Disaster risk reduction strategies and risk management practices: Critical elements for adaptation to climate change. In Submission to the UNFCCC Adhoc working group on long term cooperative action.

Jonkman, S.N. 2005. Global perspectives on loss of human life caused by floods. Natural Hazards 34 (2): 151-175.

Jung, J.W., H.N. Park, D.H. Choi, S.S. Baek, K.S. Yoon, W.J. Baek, J.A. Beam, and B.J. Lim. 2013. Analysis of first flush of recreation park and removal rate according to rainfall-runoff storage depth. Journal of Korean Society on Water Environment 29 (5): 648-655.

Kanth, T.A., and Z. Hassan. 2012. Morphometric analysis and prioritization of watersheds for soil and water resources Management in Water Catchment using geo spatial tools. International Journal of Geology, Earth and Environmental Sciences 2: 30-41.

Krishnamurthy, J., G. Srinivas, V. Jayaram, and M.G. Chandrasekhar. 1996. Influence of rock types and structures in the development of drainage networks in typical hard rock terrain. ITC Journal 3 (4): 252-259.

Kumar, R., S. Kumar, A.K. Lohani, R.K. Nema, and R.D. Singh. 2000. Evaluation of geomorphological characteristics of a catchment using GIS. GIS India 9 (3): 13-17.

Kumar, T., A.K. Gautam, and D.C. Jhariya. 2016. Multi-criteria decision analysis for planning and management of groundwater resources in Balod District, India.
Environmental Earth Science 75 (649) https://doi.org/10.1007/s12665-0165462-3.

Langbein, W.B. 1947. Topographic characteristics of drainage basins. U.S Geological Survey Water Supply Paper 986: 157-159.

Lenderink, G., and E. van Meijgaard. 2008. Increase in hourly precipitation extremes beyond expectations from temperature changes. Nature Geoscience 1: 511-514.

Miller, J.D., and M. Hutchins. 2017. The impacts of urbanization and climate change on urban flooding and urban water quality: A review of the evidence concerning the United Kingdom. Journal of Hydrology and Regional Studies 12: 345-362 https://doi.org/10.1016/j.ejrh.

Miller VC.1953. A quantitative geomorphic study of drainage basin characteristics in the Clinch Mountain area, Varginia and Tennessee, project NR 389042, tech Rept 3., Columbia University, department of Geology. 1-30.

Moglen, G.E., E.A. Eltahir, and R.L. Bras. 1998. On the sensitivity of drainage density to climate change. Water Resource Research 34: 855-862.

Nijland, H.J. 2005. Sustainable development of floodplains (SDF) project. Journal of Environmental Science and Policy 8: 245-252.

Nyamathi, S.J., Kavitha, B. 2013. Morphometric analysis and runoff estimation of a catchment using different data set", Research and Reviews: Journal of Engineering and Technology. Volume 2, No 13, July - September, 2013, pp. 87-94.

Ologunorisa, T.E., and A. Adejumo. 2005. Public perception of flood Hazard in the Niger Delta, Nigeria. The Environmentalist 25 (1): 39-45.

Ozdemir, H., and D. Bird. 2009. Evaluation of morphometric parameters of drainage networks derived from topographic maps and DEM in point of floods. Environmental Geology 56: 1405-1415.

Panhalkar, S., and B. Gowtham. 2011. Site suitability analysis for ground water recharge in Dudhaganga Bain, India, a geo-informatics approach. National Journal of chembiosis 2 (1): 1-13.

Prinz, D., and A. Singh. 2000. Technological Potential for Improvements of Water Harvesting. Germeny: Prepared for Thematic Review IV.2: Assessment of Irrigation Options http://www.dams.org/.

Ramaiah, S.N., G.S. Gopalakrishna, S. Srinivasa, and Md Najeeb. 2012. Morphometric analysis of sub-basins in and around Malur Taluk, Kolar District, Karanataka using remote sensing and GIS techniques. Journal of Nature Environment and Pollution Technology 11: 89-94.

Ratnam, K.N., Y.K. Srivastava, and V.R. Venkateswara. 2005. Check dam positioning by prioritization of micro-watersheds using SYI model and morphometric analysis -remote sensing and GIS perspective. Journal of the Indian Society of Remote Sensing 33: 25-38.

Rudraiah, M., S. Govindaiah, and V.S. Srinivas. 2008. Morphometry using remote sensing and GIS techniques in the sub-basins of Kagna river basin, Gulburga district, Karnataka, India. Journal of Indian Society of Remote Sensing 36: 358.

Schumm, S.A. 1956. Evolution of drainage systems and slopes in badlands at Perth Amboy, New Jersey. Geological Society of American Bulletin 67: 597-646.

Shang, J., and P. Wilson. 2009. Watershed urbanization and changing flood behavior across the Los Angeles metropolitan region. Natural Hazards 48: 41-57.

Singh, P., A. Gupta, and M. Singh. 2014. Hydrological inferences from watershed analysis for water resource management using remote sensing and GIS techniques. Egyptian Journal of Remote Sensing Space Science 17: 111-121.

Singh, S., and M.C. Singh. 1997. Morphometric analysis of Kanhar river basin. National Geographical Journal of India 1: 31-43.

Smith, K.G. 1950. Standards for grading textures of erosional topography. American Journal of Sciences 248: 655-668.

Strahler, A.N. 1964a. Quantitative geomorphology of drainage basins and channel networks. In Handbook of applied hydrology, ed. V.T. Chow, 439-476. New York: McGraw-Hill.

Strahler, A.N. 1964b. Quantitative geomorphology of drainage basins and channel networks section 4-2, handbook of applied hydrology, Ven Te chow, 4-35. New York: McGraw-Hill.

Verstappen, H.T. 1995. Aerospace technology and natural disaster reduction. In Natural hazards: Monitoring and assessment using remote sensing technique, ed. R.P. Singh and R. Furrer, 3-15. Oxford: Pergamon Press.

Yonas, T.A. 2015. Increased frequency of flash floods in Dire Dawa, Ethiopia: Change in rainfall intensity or human impact? Natural Hazards 76 (2): 13731394.

Youssef, A.M., B. Pradhan, and A.M. Hassan. 2011. Flash flood risk estimation along the St. Katherine road, southern Sinai, Egypt using GIS based morphometry 
and satellite imagery. Environ Earth Science 62: 611-623 https://doi.org/10. 1007/s12665-010-0551-1.

Youssef, A.M., B.D. Pradhan, A.F. Gaber, and M.F. Buchroithner. 2009. Geomorphological hazard analysis along the Egyptian Red Sea coast between Safaga and Quseir. Natural Hazards and Earth System Sciences 9 (3): 751.

Youssef, A.M., S.A. Sefry, B. Pradhan, and A.E. Alfadail. 2016. Analysis on causes of flash flood in Jeddah city (Kingdom of Saudi Arabia) of 2009 and 2011 using multi-sensor remote sensing data and GIS. Geomatics, Natural Hazards and Risk 7 (3): 1018-1042. https://doi.org/10.1080/19475705.2015.1012750.

Submit your manuscript to a SpringerOpen ${ }^{\mathcal{O}}$ journal and benefit from:

- Convenient online submission

- Rigorous peer review

- Open access: articles freely available online

- High visibility within the field

- Retaining the copyright to your article

Submit your next manuscript at $\boldsymbol{\nabla}$ springeropen.com 